\title{
Gas Hydrate Accumulation and Occurrence Associated with Cold Seep Systems in the Northern South China Sea: An Overview
}

\author{
Wei Zhang $\mathbb{D}^{1,2}$ Jinqiang Liang, ${ }^{1,2}$ Qianyong Liang, ${ }^{1,2}$ Jiangong Wei $\mathbb{D}^{1,2}$ Zhifeng Wan ${ }^{1 D},^{3}$ \\ Junxi Feng, ${ }^{1,2}$ Wei Huang, ${ }^{1,2}$ Jing Zhao, ${ }^{1,2}$ Miaomiao Meng, ${ }^{1,2}$ Wei Deng, ${ }^{1,2}$ \\ and Chongmin Chen ${ }^{3}$ \\ ${ }^{1}$ MNR Key Laboratory of Marine Mineral Resources, Guangzhou Marine Geological Survey, Ministry of Natural Resources, \\ Guangzhou 510075, China \\ ${ }^{2}$ Southern Marine Science and Engineering Guangdong Laboratory (Guangzhou), Guangzhou 511458, China \\ ${ }^{3}$ School of Marine Sciences, Sun Yat-sen University, Zhuhai 519000, China
}

Correspondence should be addressed to Jiangong Wei; weijiangong007@163.com and Zhifeng Wan; wanzhif@mail.sysu.edu.cn

Received 11 March 2021; Revised 29 June 2021; Accepted 30 August 2021; Published 5 October 2021

Academic Editor: Jinze Xu

Copyright (C) 2021 Wei Zhang et al. This is an open access article distributed under the Creative Commons Attribution License, which permits unrestricted use, distribution, and reproduction in any medium, provided the original work is properly cited.

\begin{abstract}
Studying deep-water cold seep systems is of great significance to gas hydrate exploration due to their close relationship. Various cold seep systems and related gas hydrate accumulations have been discovered in the northern South China Sea in the past three decades. Based on high-resolution seismic data, subbottom profiles, in situ submergence observations, deep drilling and coring, and hydrate gas geochemical analyses, the geological and geophysical characteristics of these cold seep systems and their associated gas hydrate accumulations in the Qiongdongnan Basin, the Shenhu area, the Dongsha area, and the Taixinan Basin have been investigated. Cold seep systems are present in diverse stages of evolution and exhibit various seabed microgeomorphic, geological, and geochemical features. Active cold seep systems with a large amount of gas leakage, gas plumes, and microbial communities and inactive cold seep systems with authigenic carbonate pavements are related to the variable intensity of the gas-bearing fluid, which is usually derived from the deep strata through mud diapirs, mud volcanoes, gas chimneys, and faults. Gas hydrates are usually precipitated in cold seep vents and deeper vertical fluid migration pathways, indicating that deep gas-bearing fluid activities control the formation and accumulation of gas hydrates. The hydrocarbons collected from cold seep systems and their associated gas hydrate reservoirs are generally mixtures of biogenic gas and thermogenic gas, the origin of which is generally consistent with that of deep conventional gas. We also discuss the paragenetic relationship between the gas-bearing fluid and the seafloor morphology of cold seeps and the deep-shallow coupling of gas hydrates, cold seeps, and deep petroleum reservoirs. It is reasonable to conclude that the deep petroleum systems and gasbearing fluid activity jointly control the development of cold seep systems and the accumulation of gas hydrates in the northern South China Sea. Therefore, the favorable areas for conventional oil and gas enrichment are also prospective areas for exploring active cold seeps and gas hydrates.
\end{abstract}

\section{Introduction}

Cold seeps are seafloor manifestations of a gush or seepage of gas-bearing fluid migrating from beneath the seafloor into the seabed and finally into the water column. They are accompanied by a type of local abnormal sea water with various shapes, such as plumes, columns, and whips, which differ from the physical properties of the surrounding sea water [1-7]. A series of geological, geophysical, geochemical, and biological processes occur within a cold seep and the surrounding seawater, which are known as a cold seep system or a submarine methane seep system [8-12]. Generally, the activity of a cold seep is episodic and is in a dynamic state of formation and evolution [13, 14]. For those with relatively young formation ages, there may be only gushing and seepage of gas or fluids under the sea floor and associated biological communities but no methane carbonate pavements. In contrast, due to the long-time frame of the formation and 
evolution and the influence of tectonic movement, either the gas under the sea floor leaks out or the passage may be blocked by carbonate rocks or gas hydrates, so the gas plume and seepage of the cold seep to diminish and cease and the biological communities gradually die out, leaving only large-scale authigenic carbonate rocks [15-18].

Fluid seepage/leakage associated with a cold seep system is a natural phenomenon that widely exists in the Earth system, especially in marine environments [19-23]. This term refers to the complex network formed by the migration of deep gas-bearing fluids from the deep crustal rocks and sediments to the subsurface strata and seabed through different types of migration pathways, which are able to transport oil and gas and other fluids from the deep strata into the shallow gas hydrate stability zone (GHSZ) where gas hydrates can precipitate and accumulate $[13,24,25]$. In addition, a large amount of gas may even escape into the water column and atmosphere through the submarine leakage pathway, causing changes in the sedimentary environment of the seafloor and the Earth's surface $[26,27]$. Therefore, the seepage/leakage associated with cold seep systems is often significant in the fields of energy, ocean and marine ecosystems, and global climate. This unique but widely distributed geological phenomenon has received increasing amounts of attention from researchers and has become a hot topic in related fields.

Unconventional oil and gas, e.g., shale gas, oil sands, coal-bed gas, and gas hydrates, are receiving more and more attention from governments, the oil and gas industry, and petroleum geologists [28-30]. Unlike other unconventional oil and gas resources, gas hydrates are a clean, pollution-free, energy source with high energy intensity and a wide distribution in permafrost and continental slope deep water areas and thus have a huge resource potential [31]. Additionally, as one of the more environmentally friendly energies that may replace traditional carbon resources in the future, gas hydrates have attracted special attention [32, 33]. Many countries and research institutions have invested a great deal of capitals and research effort into geological research and resource evaluation of gas hydrates $[34,35]$. In addition, offshore gas hydrate production tests have been successfully implemented in the Nankai Trough and the Shenhu area in the northern South China Sea (SCS), demonstrating the potential and hope for large-scale commercial exploitation of gas hydrates in the near future [36-38].

Cold seeps are commonly found in submarine basins in the continental and shelf regions, such as in the Gulf of Mexico $[39,40]$, the Blake Sea [12, 41], and the Mediterranean Sea $[42,43]$. Moreover, the activities of cold seeps in deepwater areas are closely related to gas hydrate systems [13, $15,44]$. First, the presence of a cold seep, especially the seeping of methane-rich gas, often provides hydrocarbons for the formation and accumulation of gas hydrates. Second, the dissociation of gas hydrates may directly result in the formation of a cold seep system. Finally, the coverage of a cold seep generally indicates the distribution area of the gas hydrates. Therefore, detecting and investigating cold seeps are one of the more effective means of exploring gas hydrates in deep sea areas. A large number of gas hydrate samples have been recovered from cold seep development areas, e.g., the Gulf of Mexico, the Black Sea, and the SCS [45-53]. In addition, gas hydrates with shallow burial depths and high saturations are usually precipitated in the area of a cold seep system. This phenomenon has been observed in the Nankai Trough, the Gulf of Mexico, and offshore of India where pore-filling and fracture-filling gas hydrates with high saturations have commonly been recovered [54-56]. The existence and dissociation of gas hydrates may cause geological and geochemical processes such as variations in the microtopography, the precipitation of carbonate rocks, methane leakage, the propagation of microbial communities, and even exposed gas hydrate mounds on the seafloor [39, 47, 48, 57-59], which are significant indications of the presence of gas hydrate accumulations. Therefore, the observation and sampling of submarine outcrops have become an important and effective method in the investigation of gas hydrate systems. The identification of microgeomorphological types related to seafloor seepage and the establishment of gas seepage patterns suitable for specific areas can provide a corresponding basis for gas hydrate prospecting. In addition, there are usually a series of microtopographical features in the seabed in gas hydrate occurrence areas, such as slumps, pockmarks, mounds, mud volcanoes, depressions, and platforms [27, 60-64]. Identifying and characterizing these seafloor features not only is of great significance to the discovery and confirmation of the existence of gas hydrates but also provides basic engineering geological information for the exploration and development of gas hydrate resources.

Most of the gas hydrate accumulation areas discovered or presumed based on global exploration have been confirmed or speculated to have a close relationship with the oil and gas migration, seepage systems, and associated submarine cold seep systems in specific areas, such as the Black Sea [24, 65], the Gulf of Mexico [25, 66], the Mediterranean Sea, the Caspian Sea [42, 67], the Hikurangi continental margin offshore of New Zealand [68, 69], and the Nankai Trough [70, 71]. Gas hydrates and conventional petroleum drilling and sampling have also demonstrated the existence of the close relationship between shallow gas hydrates and medium-deep oil and gas reservoirs in most petroliferous basins, mainly because the extensive oil and gas leakage from the deep reservoirs and source kitchens provide sufficient water and hydrocarbon sources for the formation of shallow gas hydrates. This has been demonstrated in the Gulf of Mexico Basin where cold seeps commonly occur and gas hydrates have been recovered from most deep-water oil and gas boreholes $[45,72]$. In summary, the hydrocarbon and fluid migration associated with cold seep systems not only plays an important role in the migration and accumulation processes of conventional oil and gas reservoirs but also plays an important role in the gas supply for gas hydrate accumulation.

The northern SCS is a passive continental margin, in which the Neogene tectonic activity was intense, and there are two main structural layers composed of Paleogene rift sequences and Neogene depression sequences. The abundant terrestrial clastic rocks derived from Southern China 


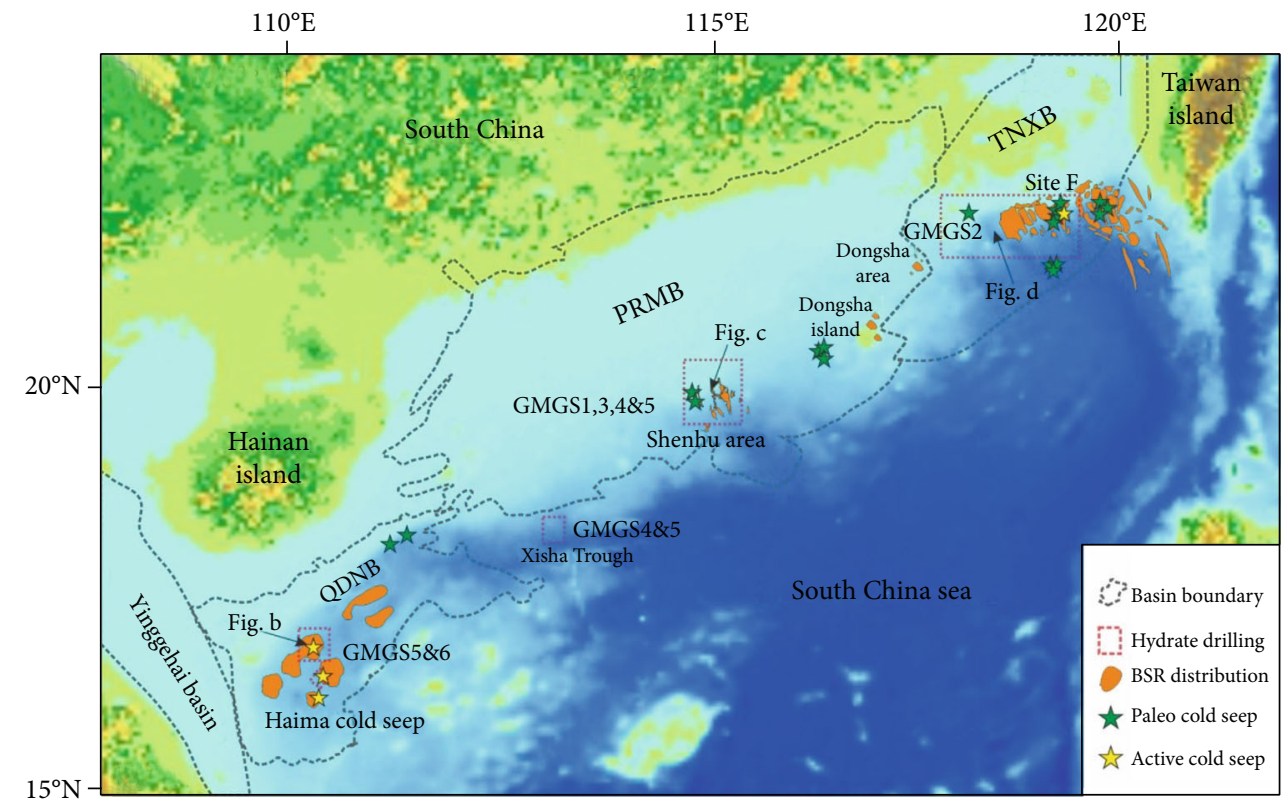

(a)

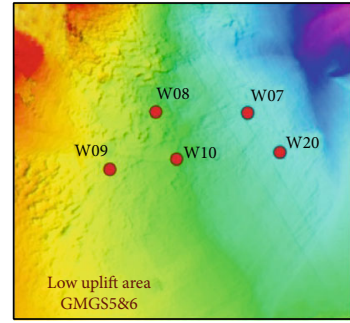

(b)

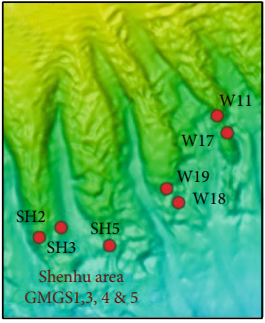

(c)

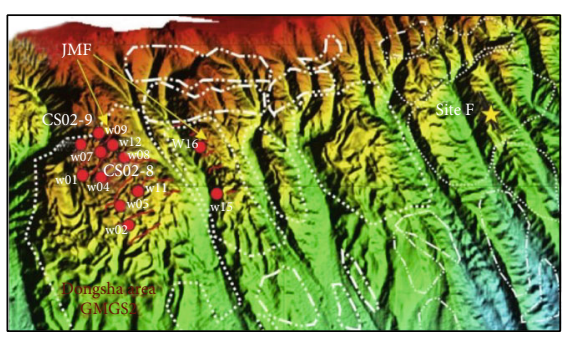

(d)

FIGURE 1: (a) Distribution of cold seep systems associated with gas hydrate accumulations in the marginal basins in the northern South China Sea. The distribution of the BSR is from Wang et al. [120], and the distribution of the cold seep system is modified after Feng et al. [6]. (b) Gas hydrate drilling zone and partial sampling sites in the low uplift area of the Qiongdongnan Basin (QDNB) for expeditions GMGS 5 and 6 [120]. (c) Gas hydrate drilling zone and partial gas hydrate drilling/coring sites in the submarine ridges in the Shenhu area in the Pearl River Mouth Basin (PRMB) for expeditions GMGS 1, 3, and 4. (d) Distribution of the gas hydrate drilling sites implemented in expedition GMGS2 and the locations of the Jiulong Methane Reef (JMF) and cold seep Site F (yellow star) in the Taixinan Basin (TXNB). The red circles indicate the location of the gas hydrate drilling/coring sites, and the white dotted lines indicate the distribution of the BSR, modified after Konno et al. [53].

and the Indochina peninsula have resulted in Neogene sediment deposits up to $\sim 10 \mathrm{~km}$ thick in the center of several petroliferous basins. The thick stratigraphic deposition and rich hydrocarbon generation and expelling processes of the deep source kitchens have led to active fluid activity, forming a series of NE trending basins that are rich in oil and gas, with widely distributed mud diapirs, mud volcanoes, gas chimneys, and submarine cold seeps [62, 73-78]. Numerous acoustic surveys, including $2 \mathrm{D}$ and $3 \mathrm{D}$ seismic, subbottom profiles, and multibeam investigations, as well as extensive deep sea diving observations, sampling, and gas hydrate drilling and coring [17, 49-51, 76, 79-82], have been carried out in the northern SCS. The number of cold seeps and associated gas hydrate accumulations being discovered is continuously increasing. Since the discovery of the first cold seep system in the northern SCS in 2004, more than 40 active and paleo-cold seeps have been discovered in the Qiongdongnan Basin, the Xisha area, the Shenhu area, the Dong- sha area, and the Taixinan Basin $[6,83]$. Among them, the cold seep found at Site F offshore of southwest Taiwan in 2013 [17] and the Haima Cold Seep discovered in the deep water Qiongdongnan Basin in 2015 are typical active cold seep systems (Figure 1) [49, 50, 84]. Since 2007, the Guangzhou Marine Geological Survey (GMGS) has carried out six gas hydrate scientific drilling expeditions in the Shenhu area and the Xisha area (GMGS1, GMGS3, and GMGS4), the Dongsha area (GMGS2), and the Qiongdongnan Basin (GMGS5 and GMGS6) in the northern SCS [51, 74, 76, 79, 80, 82, 85-91]. Except for the Xisha area, gas hydrate samples have been recovered in several regions where cold seep systems have been discovered. In addition, the Chinese Academy of Sciences has also found exposed seafloor gas hydrates related to a submarine active cold seep in the Taixinan Basin [47, 48, 53]. These gas hydrate accumulations, which are related to the development and evolution of the cold seep system, are mainly distributed in the vicinity of 
the low uplift, submarine ridge, and the channel-levee system and on the seabed above the deep faults, large mud diapirs, and gas chimneys. Therefore, the development and evolution of cold seeps and the precipitation and accumulation of gas hydrates may be closely related to the deep strata and petroleum system. However, at present, most previous studies have focused on the activities of cold seeps and their possible indications for gas hydrate accumulation in shallow and subsurface sediments. Furthermore, there is a lack of research on deep-shallow coupling of submarine cold seeps, associated gas hydrate accumulations, and deep petroleum systems. Therefore, the purposes of this review are (1) to investigate the seafloor geomorphology and geological and geophysical characteristics of the cold seep systems and associated gas hydrate accumulations that have been drilled and sampled in the northern SCS; (2) to discuss the relationship between gas hydrate accumulation and the development and evolution of cold seeps; and (3) to determine the deep-shallow coupling mechanism of cold seep systems, their associated gas hydrate accumulations, and deep petroleum systems. We hope this review will prove helpful in cold seep research and gas hydrate exploration in the SCS and regions with similar geologic settings.

\section{Submergence Observations and Sampling in Cold Seep Systems}

Based on the comprehensive interpretation and analysis of 2D/3D seismic data, subbottom and multibeam data, and manned deep submersible (HOV) and/or unmanned deep submersible (ROV) observations and sampling, scholars are able to investigate submarine cold seep systems in situ, and our understanding of the cold seep system in the northern SCS has been greatly improved [92-102]. Through submergence observations and sampling, several regions of a cold seep system and its associated gas hydrate accumulations have been discovered (Figure 1(a)). However, active cold seeps have only been discovered in the Qiongdongnan Basin, the Dongsha area, and the Taixinan Basin. The detailed results of the investigation are presented below.

In 2004, China and Germany jointly conducted the SO177 Expedition in the deep water area near Dongsha on the northern continental slope of the SCS, and for the first time, giant distributions of carbonate rocks formed by the seepage from cold seeps were discovered. These cold seep authigenic carbonates are mainly distributed on two submarine ridges with water depths of 550-650 m and 750-800 m, covering an area of $430 \mathrm{~km}^{2}$, which is the largest authigenic carbonate distribution area discovered so far worldwide [92, 93]. This area was named the Jiulong Methane Reef (Figure 1(d)). Chemoautotrophs were found in the cracks of the carbonate crust of the Jiulong Methane Reef. According to isotopic dating, the carbonate crust in this area began to form about 46,700 years ago and is still releasing methane gas. In 2012, an underwater unmanned vehicle (ROV) was used by the GMGS to obtain chimney-like cold seep carbonate rock samples from the Dongsha area (Figure 2(a)). These seabed outcrop observations and sample collection revealed that there are a large number of cold seep vents in this area.
Among them, the paleo-cold seep area is mainly the remains of the paleo-chemical reef, and there are almost no bivalve and bacterial mats. However, benthic organisms and bacterial mats were observed in the current active area of the cold seep. In addition, the Jiulong Methane Reef was later confirmed to be a gas hydrate accumulation area through deep gas hydrate drilling by the GMGS in 2013 [85, 86, 94]. Fracture-filling gas hydrates with various occurrences, including massive, laminated, nodular, and veins, were confirmed to be distributed in multiple layers, and the obtained carbonate rocks indicate that multiple periods of cold seep activity have occurred, which were related to the dissociation of gas hydrates in the past [52]. In the same year, the Jiaolong HOV conducted its first scientific research voyage in the active cold seep area of the Jiaolong-1 site (Site F) to the southwest of Taiwan, and the intermittent activity of this cold seep system was initially identified [17] (Figure 2(b)).

In the deep waters of the Taixinan Basin offshore of southwest Taiwan, scholars not only collected authigenic carbonate rock samples that record cold seep activity from five sites on the Gaoping Slope [95] but also discovered very active cold seeps on the seafloor of the Formosa Ridge (Figure 2(c)). Through ROV in situ observations, living organisms such as methane mats, mussels, and white crabs living in hydrothermal vents were observed on the seabed [96]. In addition, wide distributions of bottom simulating reflectors (BSRs) have been confirmed offshore of southwest Taiwan via high-resolution seismic data [97] (Figure 1(a)). The increasing geological, geophysical, and geochemical findings indicate that the gas hydrate resources in the Taixinan Basin have a great potential [98-100].

In 2015, the GMGS conducted ROV surveys of five sites in the deep water Qiongdongnan Basin using the selfdeveloped Haima ROV, 4500-meter unmanned submersible vehicle in order to collect image evidence related to gas hydrates and to obtain samples of carbonate rocks and chemoautotrophs related to active submarine cold seeps. Three sampling sites were chosen in the southern low uplift area of the Qiongdongnan Basin, and push core and piston core samples containing massive gas hydrates were obtained at two of these three sites $[49,50,77]$. A giant active cold seep, which was named the Haima Cold Seep, with water depths of $1350-1430 \mathrm{~m}$ and an area of $\sim 618 \mathrm{~km}^{2}$, was discovered for the first time in the northwestern area of the SCS (Figure 2(d)). Piston coring was used to directly sample the shallow surface sediments in the Haima Cold Seep. Physical samples of massive gas hydrates were successfully obtained from depths of 7.95-8.20 $\mathrm{m}$ and $4.95-5.10 \mathrm{~m}$ below the sea floor at the two sampling sites with water depths of $1381 \mathrm{~m}$ and $1405 \mathrm{~m}[49,50]$. New understandings of the gas hydrate accumulation mechanism and the development of the seafloor ecosystem related to cold seeps in the SCS were gained, promoting subsequent cold seep investigation and gas hydrate drilling site optimization in the Qiongdongnan Basin [77]. In 2018, the QH-ROV-2018 voyage led by the GMGS carried out continuous observations in the Haima Cold Seep area and the northeastern deep-water area of the Qiongdongnan Basin in order to determine whether there are geomorphic phenomena related to submarine leakage 


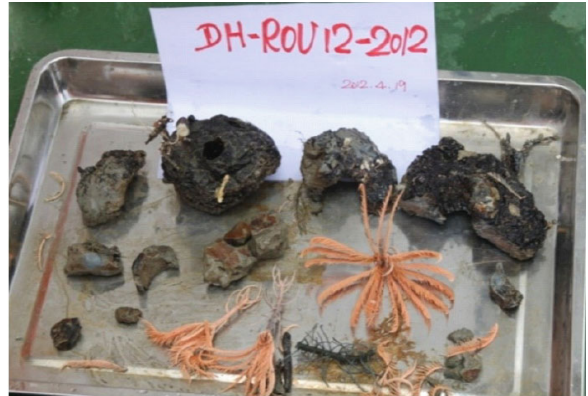

(a)

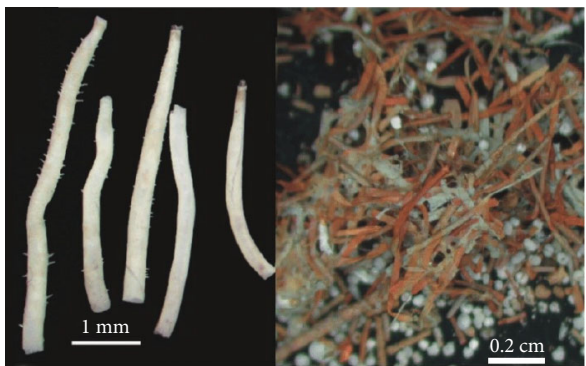

(c)

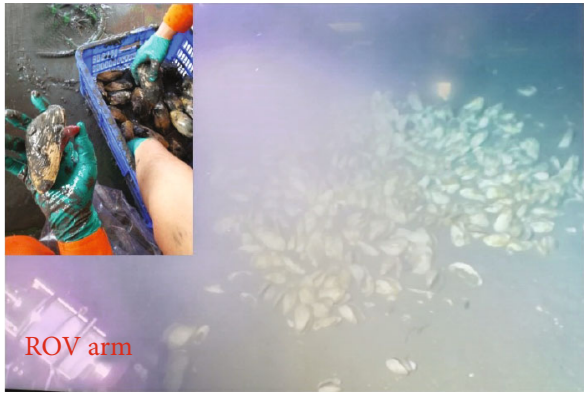

(e)

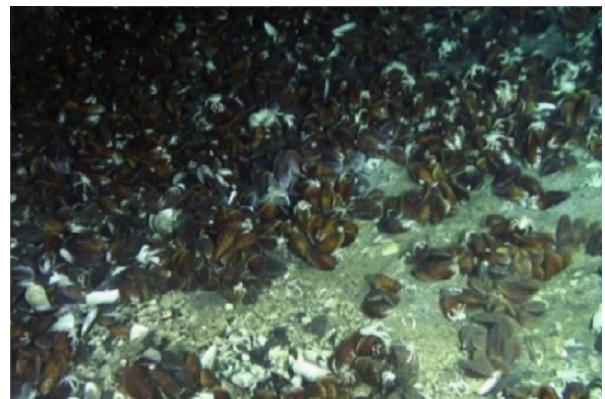

(b)

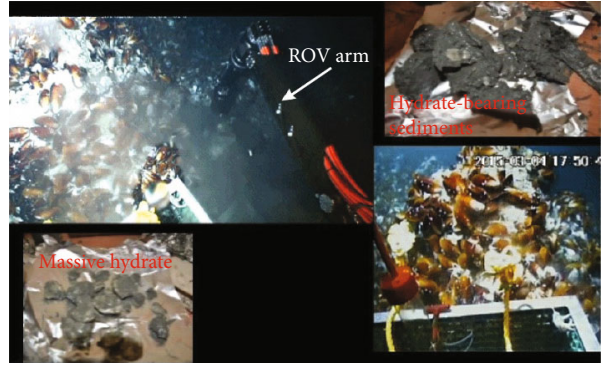

(d)

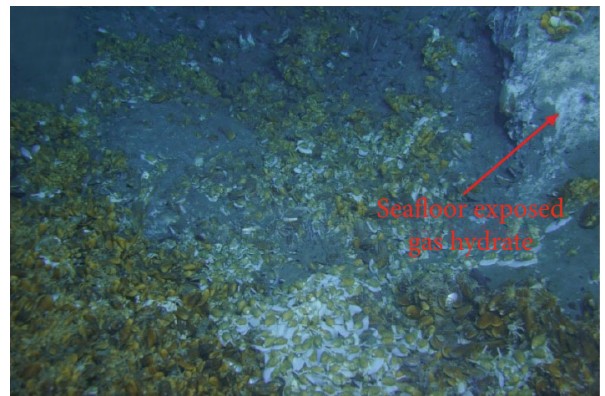

(f)

Figure 2: (a) Chimney-like carbonate crusts recovered from the Jiulong Methane Reef. (b) Microbial communities found at the active cold seep in Site F [17]. (c) Tube worms and specimens obtained from the Gaoping slope in the Taixinan Basin [95]. (d) Carbonates, bivalve communities, and massive gas hydrates recovered from the Haima Cold Seep. (e) Bivalve communities discovered by the Haima ROV in a new cold seep developed in the GMGS5 gas hydrate drilling zone, northeastern the Haima Cold Seep. (f) Microbial communities, carbonate crust, and gas hydrates exposed on the seafloor, discovered in a new cold seep near the Haima Cold Seep.

and microbial communities related to active cold seeps in the selected survey sites (Figure 2(e)). These observations provided more direct information for the exploration, drilling, and sampling of gas hydrates in a later GMGS5 expedition $[51,101]$. Through Haima ROV observations, seabed microbial communities were found in two of the main investigation sites. Using the sampling manipulator arm, sampling grab, and shallow drilling rig of the Haima ROV, bivalve organisms were collected, and carbonate rock samples were obtained via push coring [102]. In the same year, the Haima ROV of the GMGS and the Deep Sea Warrior HOV of the Sanya Deep Sea Research Institute conducted a joint deep-diving investigation in the Haima Cold Seep and its eastern area, which provided abundant precious information and data for further research of the cold seep and for evaluation of its gas hydrate resource potential [84] (Figure 2(f)).

\section{Geophysical Indications of Cold Seeps and Gas Hydrates}

There are usually a series of microtopographic features in the seabed in gas hydrate accumulation areas, such as slumps, pockmarks, mounds, mud volcanoes, depressions, platforms, and cold seeps. Identifying and characterizing these seafloor features not only is of great significance to the discovery and confirmation of gas hydrate systems but also can provide basic engineering geological data for the exploitation of the gas hydrate resources. Through a comprehensive study of the seismic, subbottom profile, and ROV image data for the target area for cold seep and gas hydrate exploration in the northern SCS, a variety of seismic and acoustic reflection features related to fluid seepage/leakage were recognized, including gas plumes, seabed mounds, pockmarks, acoustic blanking, and acoustic turbidity [47-50, 


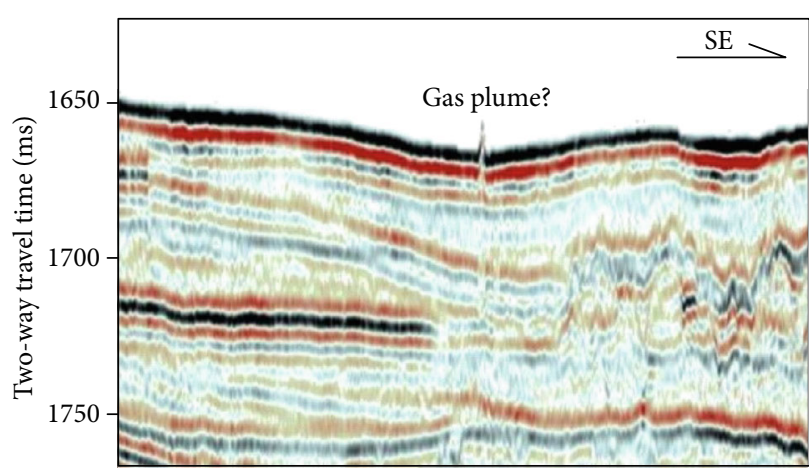

(a)

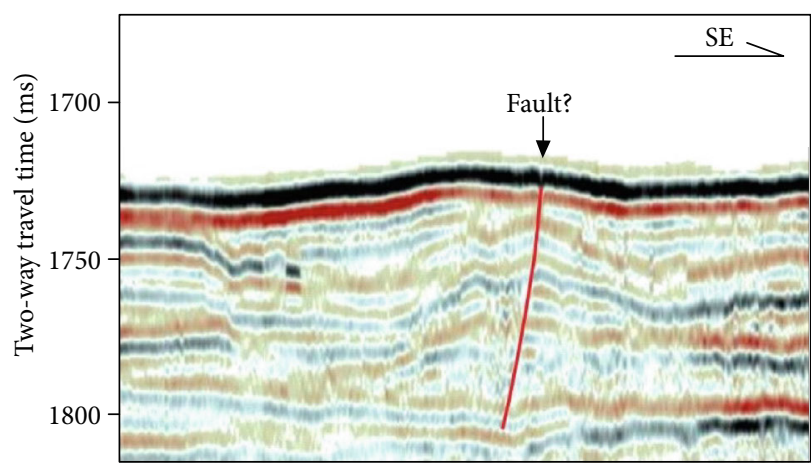

(c)

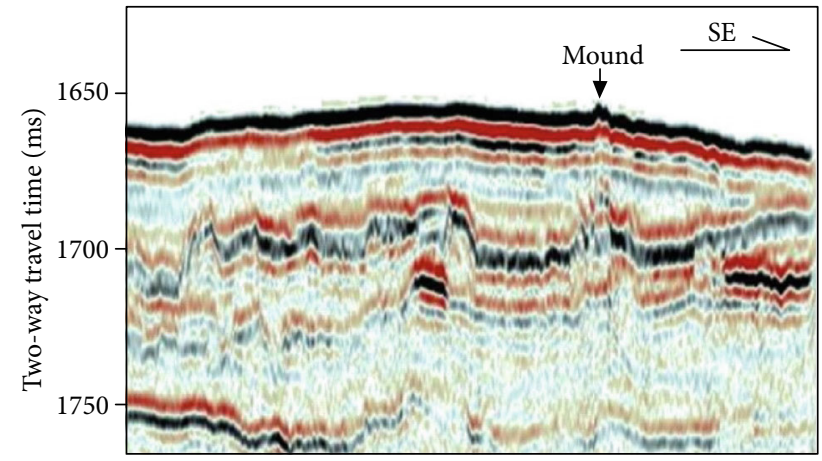

(b)

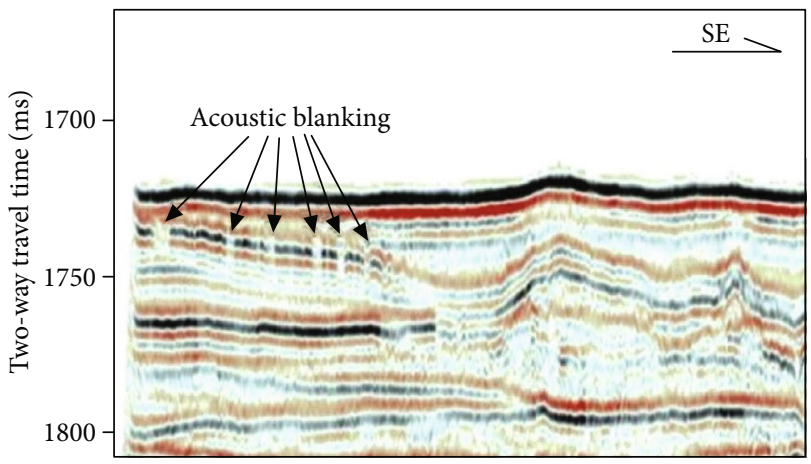

(d)

FIGURE 3: Seismic profiles showing the seabed microgeomorphological features related to gas seepage in the deep-water Qiongdongnan Basin.

$62,64,77,103-106]$. In addition, microbial communities, bacterial mats, methane biochemical reefs, and carbonate crusts associated with cold seeps have been found in the Qiongdongnan Basin, the Xisha Trough, the Dongsha area, and the Taixinan Basin in the northern SCS (Figure 2) [17, $47-49,52,101,107,108]$. These seafloor seepage phenomena, especially the discovery of gas plumes, suggest that the gas source in the study area is sufficient. The appearance of a large number of bivalves and bacterial mats is often a sign of a cold seep with active methane seepage, while carbonate crusts may indicate the cessation of methane seepage. These signs also indicate that gas hydrates are likely to accumulate in the cold seep area.

Based on the fine interpretation of a 3D seismic profile in the Qiongdongnan Basin, many geophysical anomalies closely related to gas seepage were identified in the deepwater area (Figure 3 ). In addition, a large number of seabed pockmarks, mounds, and acoustic blanking reflections, which are indicative of the presence of free gas and gas hydrates, were identified on the subbottom profile (Figure 4). The reflection of the acoustic blanking reflects the gas-bearing strata, which is consistent with the local structural high, indicating the accumulation characteristics of the gas at the high point. Small mounds, i.e., tens to hundreds of meters in diameter, were interpreted on top of the acoustic blanking, indicating the accumulation and seepage of gas from depth. The presence of large flourishing biological communities often indicates the presence of current methane seepage, which is likely related to the dissociation of the gas hydrates precipitated in the shallow strata. The commonly occurring microtopography of the seabed and the acoustic anomalies suggest that there is distinct hydrocarbon leakage, indicating a good prospect for gas hydrate occurrence in the deep water Qiongdongnan Basin.

On the seismic profiles, the most favorable indicator of gas hydrate occurrence is a BSR, which exhibits a high amplitude mimic of the seafloor with a negative reflection polarity and usually crosscuts the surrounding strata. A BSR is generally recognized in the overlapping strata of the low uplift and slope area of the Qiongdongnan Basin, but it is usually difficult to identify in deep sags due to the parallel deposition of the Quaternary strata (Figure 5). A BSR was clearly identified by the seismic anomalies resulting from the gas migration along the low uplift, with a fuzzy seismic reflection zone below the BSR (Figures 5(a) and 5(d)). The gas seepage pathways extending from the BSR to the seafloor were identified on the high-precision $3 \mathrm{D}$ seismic profile, which shows the "pulled-up" features of the events on both sides of the vertical pathways (Figure 5(a)). Pulled-up reflectors are usually caused by the presence of a material that is harder than the surrounding strata since the hard material can cause velocity anomalies [53, 109]. The gas hydrate drilling and sampling conducted during GMGS expeditions 5 and 6 have demonstrated that hard materials, including gas hydrates and authigenic carbonate rocks precipitated within the seepage/migration pathways, correspond to the pulledup features [76]. The piston coring and push coring also recovered gas hydrates and authigenic carbonate rocks from 


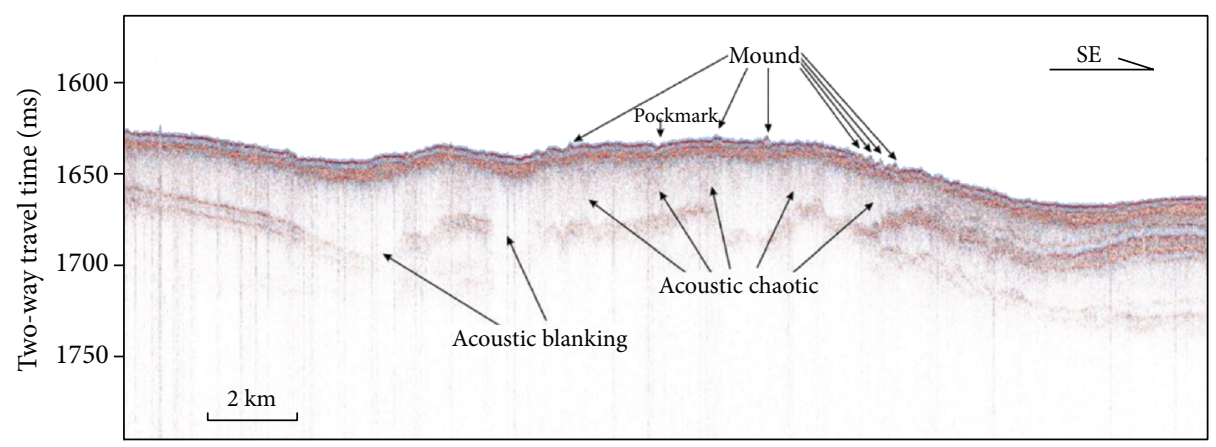

(a)

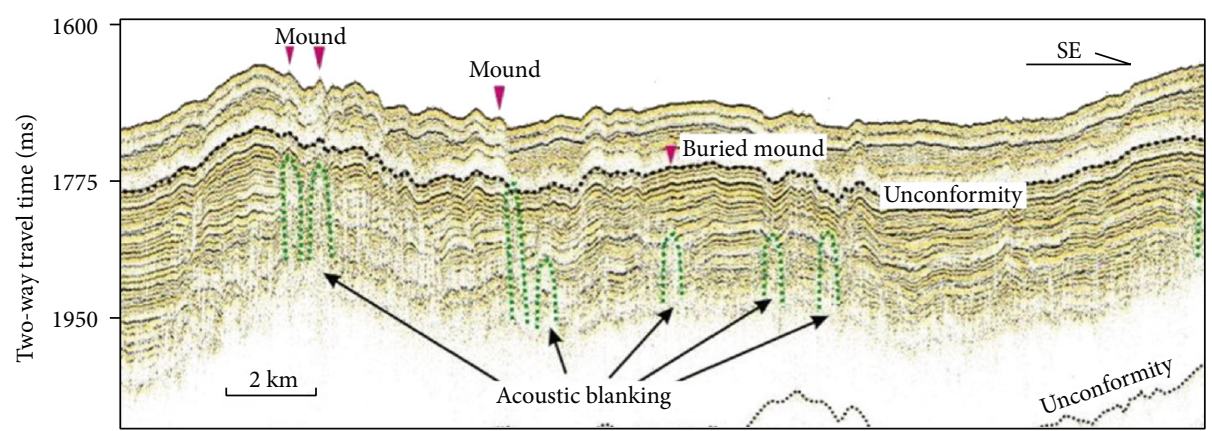

(b)

Figure 4: (a) Subbottom profile and (b) seismic profile showing the seabed microgeomorphological features related to gas seepage in the deep-water Qiongdongnan Basin.

the subsurface sediments in the seepage sites in the Qiongdongnan Basin $[49,50]$. The fracture-filling gas hydrate drilling and ROV diving site optimization in the Qiongdongnan Basin mostly targeted the seepage pathways with pulled-up features, and it was found that these seismic anomalies represent the occurrence of gas hydrates associated with carbonate rocks $[50,51,76]$. In addition, the seepage pathways usually correspond to cold seep vents on the seafloor, and this phenomenon has been commonly observed in the Haima Cold Seep (Figures 5(a)-5(c)). Anomalies with various amplitudes that are associated with seafloor seepage were observed on the seismic profiles, mainly including high amplitude bright spots associated with BSRs and large areas of blanking or chaotic reflection zones caused by mud diapirs and/or gas chimney, which promote gas migration and accumulation in the deep strata [77]. Gas hydrates and seeps have also been discovered in the shallow strata over mud diapirs and gas chimneys in the Shenhu area, the Dongsha area, and the Qiongdongnan Basin in the northern SCS.

Gas chimneys with chaotic seismic reflections and pulldown features indicating the migration and accumulation of hydrocarbons, as well as BSRs and associated seismic anomalies indicating the accumulation of gas hydrates, have been identified by interpreting the quasi-3D seismic data for the Dongsha area $[53,76,85,86]$. In addition, a large number of slumps and listric faults have been identified in the shallow strata. The above characteristics indicate the occurrence of gas seepage in the area and the possibility of the development of various submarine microgeomorphologies associated with gas seepage. A large number of blanking zones was found on the subbottom profiles $[105,106]$
(Figure 6(a)), indicating that there may be mud diapirs with a high strata pressure or faults conducive to fluid migration in this area. Based on the analysis of the subbottom profile, the acoustic blanking reflection anomalies indicating the presence of mud volcanos and gas accumulation in the shallow sediments have been observed (Figure 6(b)), and it was found that there are many pockmarks that may have been caused by submarine gas leakage $[105,106]$ (Figures $6(\mathrm{c})-$ $6(\mathrm{~h}))$. When the deep gas-bearing fluid is blocked by the shallow strata and cannot reach the seafloor, the upper strata will be deformed due to the overpressure and will form dome features in the seafloor, which is also one of the macroscopic manifestations of gas seepage below the sea floor (Figure 6(d)). Gas chimneys are commonly observed on the seismic profile in the Dongsha area [110]. In general, the internal reflections of these gas chimneys are disordered and chaotic or are characterized by acoustic blanking. In addition, the continuous reflection events on both flanks are suddenly interrupted and terminate at the edge of the chimney zone. The pulled-down phenomenon of the event can be commonly seen on the top of the gas chimney, and the bright spots on both sides and the top of the upper part are distinct (Figure 6). The low amplitude, pulled-down features are mostly caused by the low-velocity anomaly created by the gas charging. The bright spot is the enhanced reflection formed by the accumulation of free gas. Most of the gas chimneys extend from the Miocene strata to the Quaternary strata. In plan view, the gas chimneys are mainly located in the eastern and western ridges, indicating that the local structural high controls the hydrocarbon migration and accumulation (Figure 7). Vertically, the large gas 


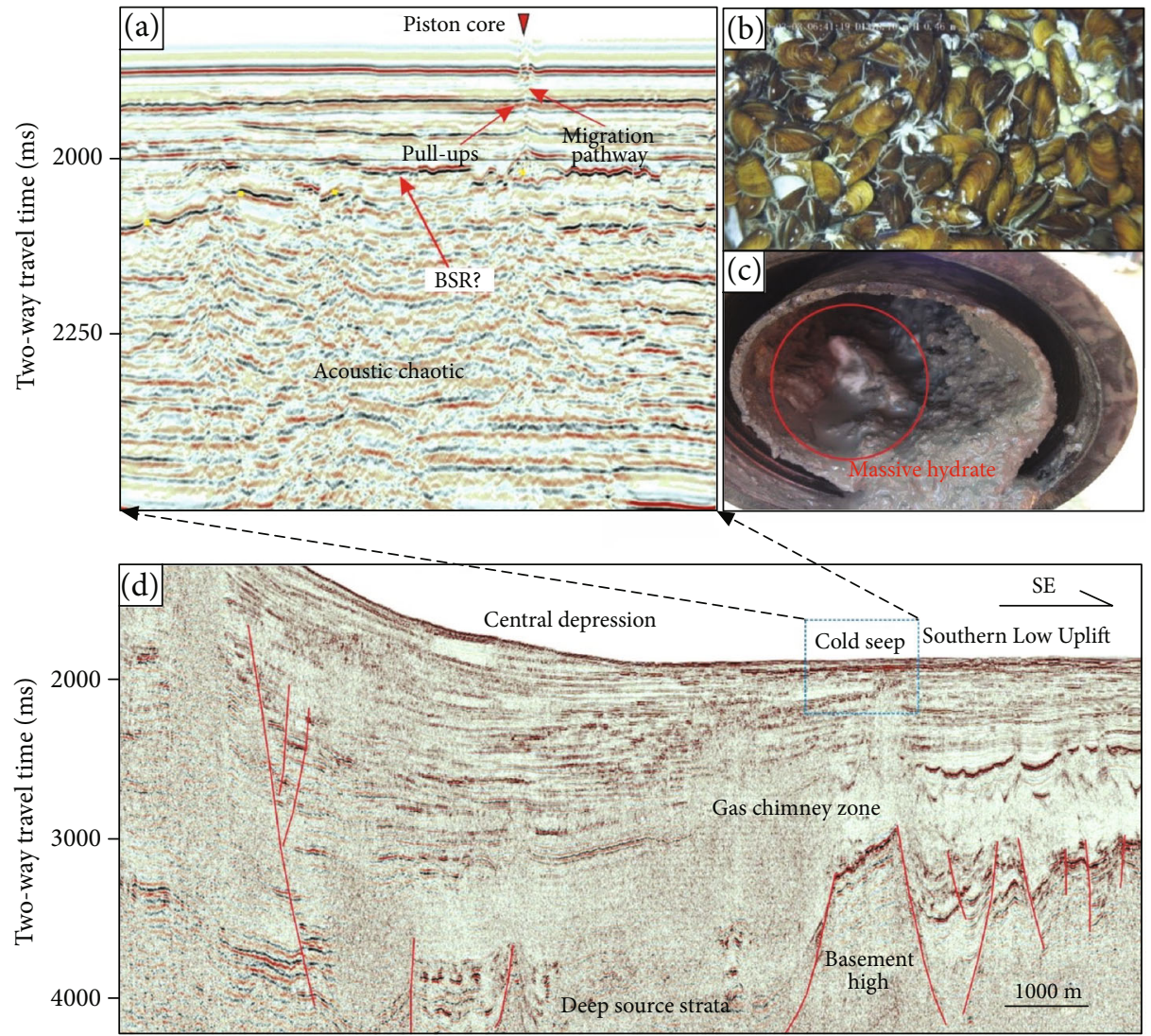

Figure 5: (a) Seismic profile showing the hydrocarbon migration and seepage features in the Haima Cold Seep. (b) Microbial communities and (c) massive gas hydrates recovered from the Haima Cold Seep (modified from [49]). (d) Seismic profile showing the deep structural features below the Haima Cold Seep in the southern low uplift area of the Qiongdongnan Basin. Large range of acoustic fuzzy zones resulting from gas chimneys can be observed on the seismic profile, indicating the upward migration of deep hydrocarbons, which supply materials for gas seepage and gas hydrate accumulation.

chimneys in the drilling area almost terminate below the $\mathrm{BSR}$, indicating that the gas-bearing fluid is enriched at the base of the gas hydrate stability zone (BGHSZ) during the upward migration, and gas hydrates precipitated under the appropriate temperature and pressure conditions $[53,62$, $97,111]$. That is, the gas chimneys control the hydrocarbon migration and gas hydrate formation and accumulation in the Dongsha area. In addition, mud diapirs and mud volcanoes have also developed in the deep-water Taixinan Basin offshore southwest of Taiwan. They exhibit a large range of vertical acoustic blanking and chaotic reflections on the seismic profile, and domes and cone-shaped structures are commonly observed in the seafloor. Continuous BSRs have been interpreted in the vicinity of the mud volcanos, mud diapirs, and gas chimneys, indicating the presence of gas hydrates (Figure 8).

Similar to the Dongsha area, the seismic profiles in the Shenhu area show that there are a large range of fuzzy reflection zones formed by diapirs and/or gas chimneys, which have a columnar or mushroom appearance in the vertical direction $[53,76,85,86]$. Bright spots were observed on the top and edges of the gas chimneys, indicating the presence of active gas-bearing fluids in the Shenhu area. BSRs are widely distributed in the study area, and very high amplitude BSRs occur in the upper parts of the gas chimneys [103,
104]. A set of amorphous enhanced reflections that are oblique to the BSR usually occur immediately above the BSR. Drilling has confirmed that these enhanced reflections indicate the presence of gas hydrates $[80,112]$ (Figure 9). With the acquisition and interpretation of high-resolution 3D seismic data, large-scale listric faults connecting the deep source kitchens, medium-deep petroleum reservoirs, and shallow GHSZ were observed in the gas hydrate accumulation zone $[103,104,113]$. In addition, it has been found that the gliding faults in the GHSZ are partially connected with the BSRs and extend upward to the seabed, constituting possible pathways by which gas can enter the GHSZ or escape and leak into the water column after gas hydrate dissociation due to slope failure. Although no active gas seepage or cold seeps have been confirmed at present, paleo-cold seep activity has been confirmed through geochemical testing of sediments recovered from the Shenhu area [114-116].

\section{Distribution of Gas Hydrate Accumulations Associated with Cold Seeps}

The seafloor observations and sampling, seismic exploration, and drilling of gas hydrates have confirmed that almost all of the regions containing cold seeps in the northern SCS are favorable regions for gas hydrate accumulation [48-51, 76, 

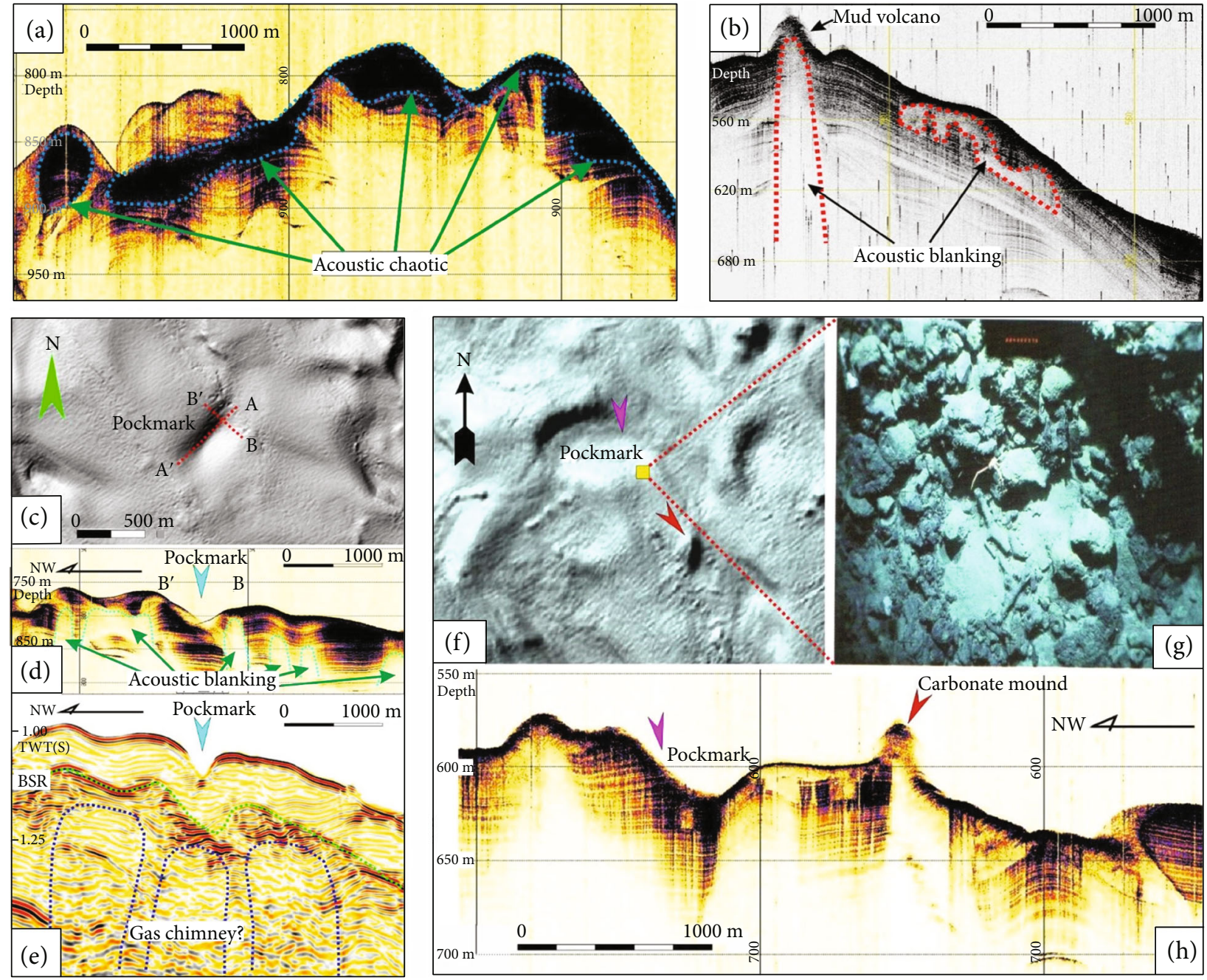

FiguRE 6: Subbottom profile and seismic profile showing the microgeomorphological features associated with the cold seep and gas hydrate accumulation in the Dongsha area (modified from Shang et al. [105] and Shang et al. [106]). The pockmarks are closely related to the gasbearing fluid migration from the deep strata, which are indicated by the acoustic blanking and the chaotic features on the subbottom and seismic profiles. The submarine mound with authigenic carbonate pavement resulted from gas hydrate dissociation and the seepage of hydrocarbons.

$86,117,118]$. Gas hydrate accumulation related to cold seep activity has been found in the development area of the paleocold seep in the Shenhu area, the development area of the active cold seep in the deep water Qiongdongnan Basin, and the development areas of the paleo-cold seep and active cold seep in the Dongsha area and the Taixinan Basin.

The GMGS1, GMGS3, and GMGS4 gas hydrate drilling expeditions and many geological surveys have been conducted in the Shenhu area, more than 60 boreholes have been drilled, and pore-filling gas hydrates with high saturations have been recovered from $\sim 160$ to $240 \mathrm{mbsf}$ through pressure coring at sites $\mathrm{SH} 2, \mathrm{SH} 3, \mathrm{SH} 7, \mathrm{~W} 11, \mathrm{~W} 17, \mathrm{~W} 18$, and W19 (Figure 1(c)) [74, 80, 87-90, 112]. In addition, authigenic carbonates associated with the strong ancient anaerobic oxidation of methane (AOM) have also been recovered, indicating a paleo-cold seep in the Shenhu area $[118,119]$. Massive shallow sediments have been recovered from piston coring sites $08 \mathrm{CF} 7$ and Site $4 \mathrm{~B}$ in the Shenhu gas hydrate accumulation area. Studies have shown that the collected authigenic carbonate minerals have a coldseep origin, and their formation indicates seafloor methane seepage and methane anaerobic oxidation (AOM) [115, 116]. In addition, the discovery of cold seep carbonate rocks reflects the continuous seepage of methane-rich fluids in this area, and it is speculated that the decomposition of gas hydrates is an important reason for the cold seep activity in this area [114]. Although the presence of gas hydrates has not been confirmed through drilling at these piston coring sites, the extensive distribution of BSRs and a large number of boreholes drilled in other parts of the Shenhu area have confirmed the widespread presence of pore-filling gas hydrates [80, 87-91, 112]. The geological and geophysical data also show that there are mud diapirs, gas chimneys, and associated fault systems in this area $[103,104,113]$. In 


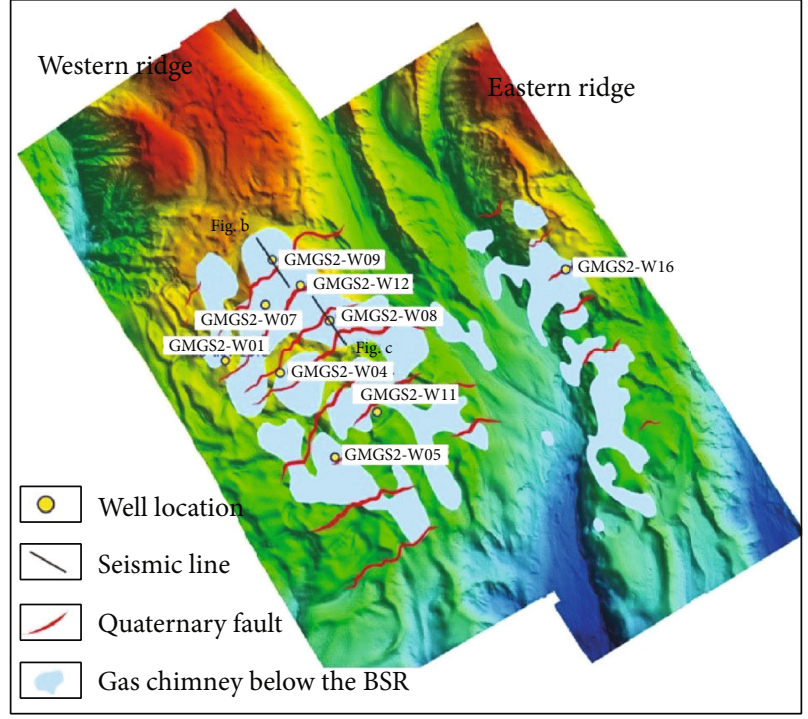

(a)

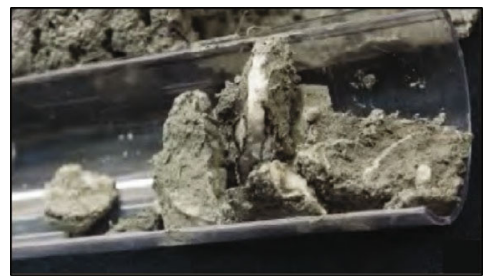

(d)

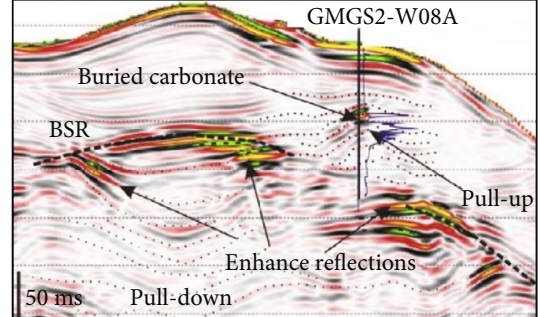

(b)

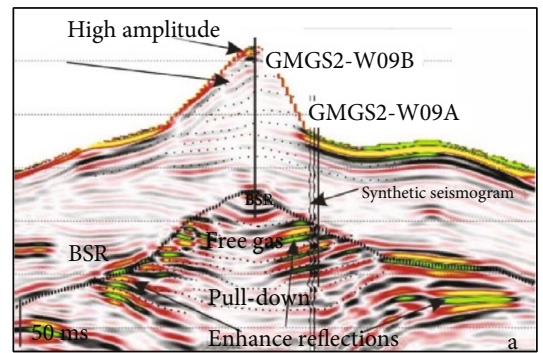

(c)

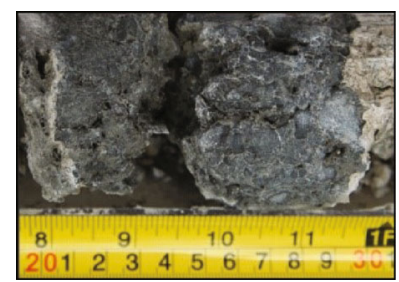

(f)

FIGURE 7: (a) Distribution of gas chimneys, faults, and gas hydrate drilling sites for the GMGS2 expedition drilling zone in the Dongsha area. The locations of the drilling sites are from Konno et al. [53] and Zhang et al. [85]. (b) and (c) Seismic profiles showing the gas hydrate accumulation features at the drilling and coring sites, where gas hydrates and buried carbonates were confirmed via logging and pressure coring (modified from Konno et al. [53]). (d) and (e) Massive gas hydrate samples collected from site GMGS2-W08 [133]. (f) Carbonate rock recovered from site GMGS2-W08 (modified from Zhong et al. [94]).

plan view, the distribution of the BSR correlates well with the distribution of the gas chimneys (Figure 9), indicating that the abundant gas supply contributes to the formation and wide distribution of the gas hydrates. Gas hydrate drilling expeditions GMGS1, 3, and 4 in the Shenhu area have demonstrated that the coring sites in which high saturation gas hydrates (up to 67\%) were drilled and obtained are directly coupled with the gas-bearing migration pathways below the BSR $[80,81,103,104,113]$. However, the accumulation of high saturation gas hydrates tens of meters thick may have prevented further seepage of the gas below the GHSZ into shallow strata and the seafloor, resulting in almost no seepage under the current geological setting.

The BSR in the deep central sag belt and southern low uplift area in the Qiongdongnan Basin has been interpreted to have a wide distribution, indicating the extensive presence of gas hydrates (Figure 1(a)), and increasing geological surveys and drilling programs have been conducted in this area in recent years $[77,120]$. In 2015, massive gas hydrate samples were obtained via piston coring of the shallow surface several meters below the seafloor in the Haima Cold Seep in the southern low uplift $[49,50]$. The gas hydrates are mainly distributed near the gas seepage vent, which is closely related to the deep free gas. In the Haima Cold Seep area, a large number of gas seepage/leakage vents have been observed on the seafloor [84]. The vertical pathways in the seafloor can be directly observed on the seismic profile, and a large amount of gas hydrates has accumulated near these pathways [49, 121]. Gas hydrate drilling expeditions GMGS5 and GMGS6 were conducted after the QH-ROV2018 ROV survey expedition, and they discovered a new cold seep system in the deep-water Qiogndongnan Basin. Fourteen sites were drilled and logged, and except for one site, all of the sites targeted fracture-filling gas hydrates within cold seep systems. In 2018, deep gas hydrate drilling expedition GMGS5 was carried out in the cold seep area at the top of the vertical seepage pathways formed by large gas chimneys in the eastern Qiongdongnan Basin, where massive, nodular, and layered gas hydrates were recovered via pressure coring of the shallow strata $(\sim 200 \mathrm{mbsf})$ at sites W07, W08, and W09 (Figure 1(b)). The gas hydrates were mainly precipitated in the fractures and small faults within the GHSZ [51, 76, 82]. Such fractures and small faults formed via gas fracturing not only constituted pathways through which the deep gas leaks into the seabed but also provided the space for gas hydrate accumulation. Therefore, the seafloor cold seep vents confirmed by the ROV and the leakage pathways identified on the seismic profile in this area 

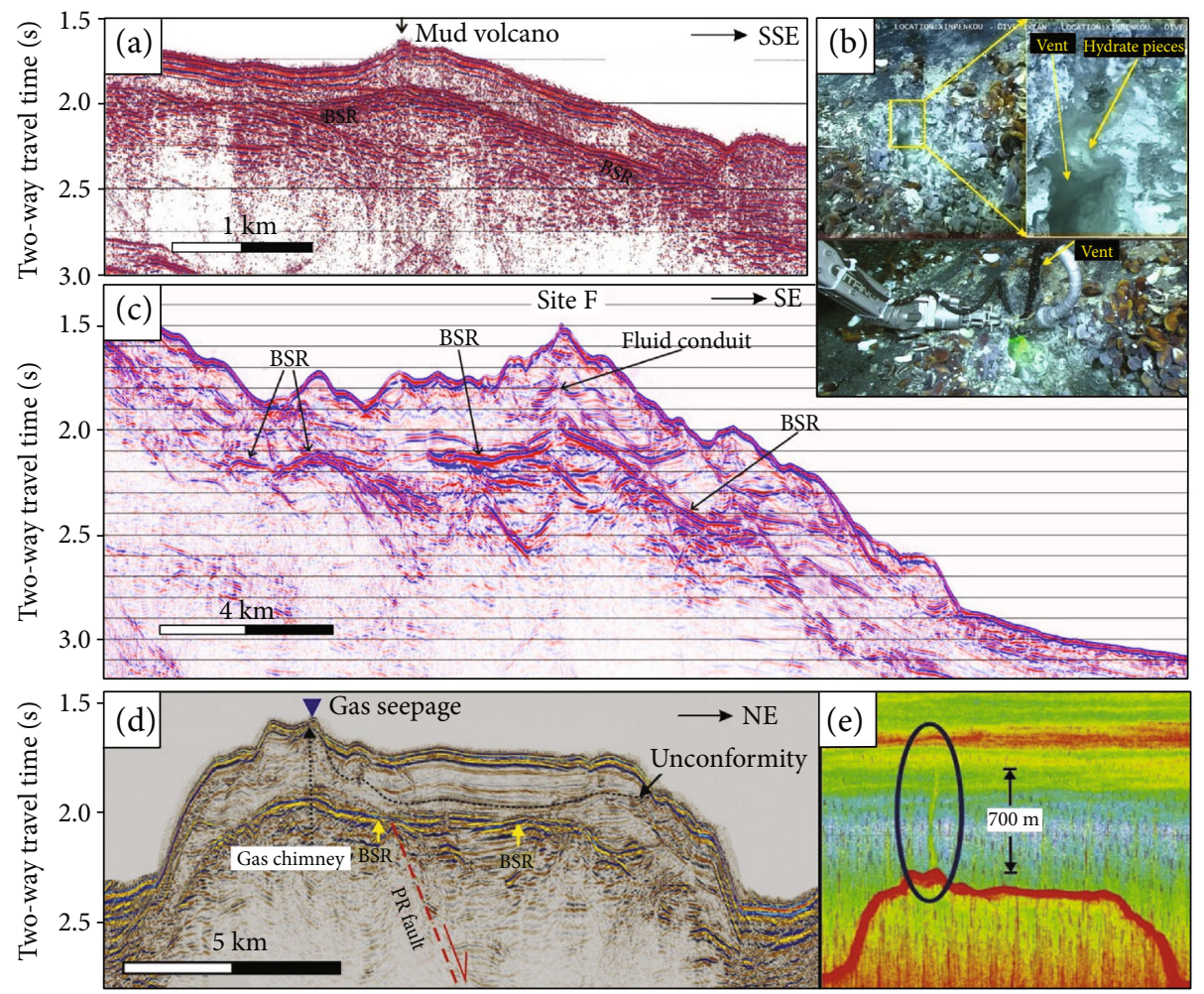

FIGURE 8: (a) Seismic profile showing the BSRs observed in the vicinity of a mud volcano developed offshore of southwestern Taiwan (modified from Liu et al. [97]). (b) Cold seep vents and gas hydrates exposed on the seafloor at site F on the Formosa Ridge [47]. (c) Seismic profile showing the gas seepage and BSRs crossing site F on the Formosa Ridge [124]. (d) Seismic profile showing the gas seepage and BSRs on Pointer Ridge [126]. (e) Gas plume detected on Pointer Ridge [126]. Fault PR is the Pointer Ridge fault.

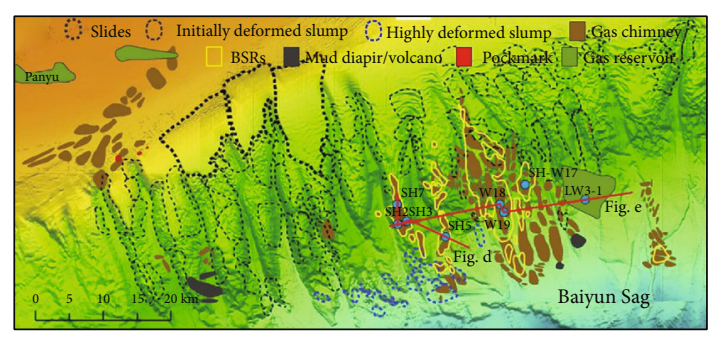

(a)

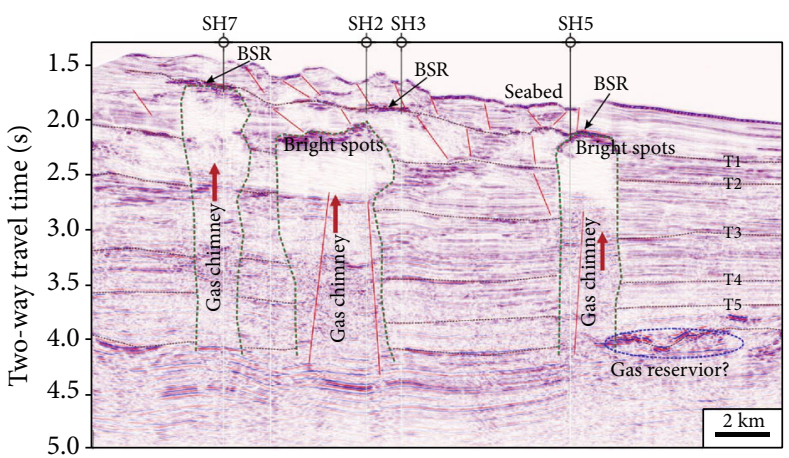

(d)

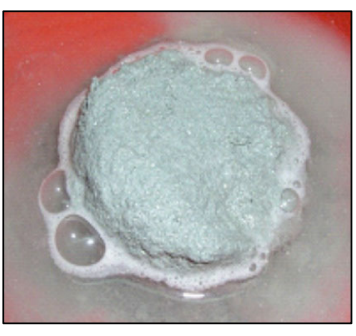

(b)

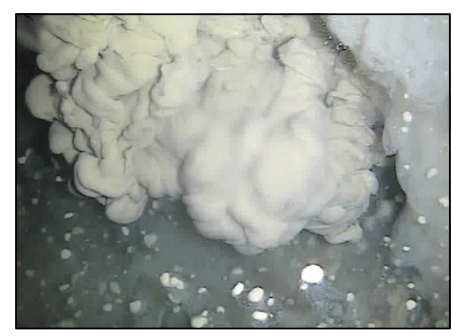

(c)

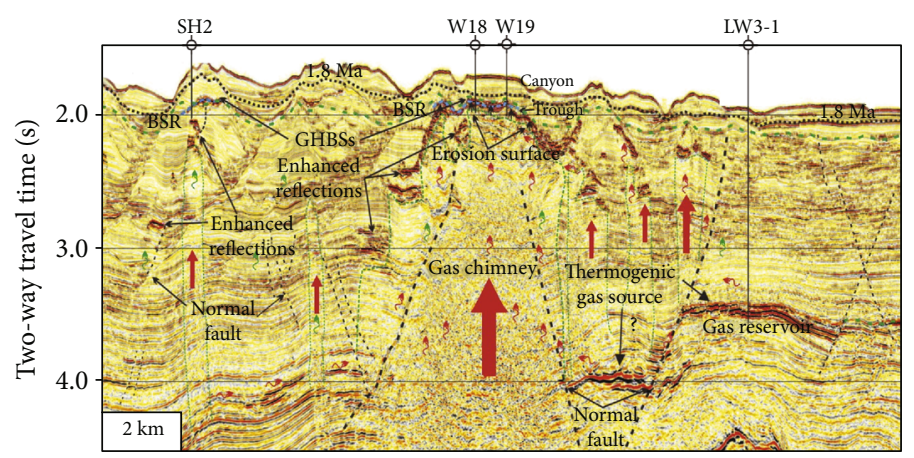

(e)

FIGURE 9: (a) Overlapping relationship between the gas chimneys, mud diapirs, mud volcanos, pockmarks, BSRs, and gas reservoir in the Shenhu area (modified from Chen et al. [103]). (b) Dissociation of pore-filling disseminated gas hydrate sample. (c) Gas hydrate floating during deep drilling [81]. (d) and (e) Seismic profiles showing the geophysical reflection characteristics of the gas hydrate drilling sites in the Shenhu area (modified from Jin et al. [138]). 
are direct indicators of the occurrence of gas hydrates. In addition, carbonate rocks have been drilled in the seabed of the cold seep area, which are the product of the dissociation of gas hydrates. This shows that the change in the GHSZ was accompanied by a variation in the deep gas flux during the cold seep activity, which resulted in multistage gas hydrate formation and dissociation [82]. In 2019, a new active cold seep system was discovered by the Haima ROV in the eastern area of the Haima Cold Seep in the deep-water Qiongdongnan Basin. Gas hydrates directly exposed on the seabed and accompanied by large gas seeps were observed, indicating that some of the gas hydrates are in the process of dissociation [122].

The seismic interpretation and gas hydrate drilling in the Donsha area have demonstrated that the distribution of the BSR is well correlated with the distribution of the gas chimneys and NE trending listric faults in plan view. In 2013, the GMGS carried out gas hydrate drilling expedition GMGS2, which targeted the gas hydrate accumulation within the Jiulong Methane Reef in the Dongsha area of the eastern Pearl River Mouth Basin. A total of 23 boreholes were drilled and logged at 13 sites (Figure 1(d)), and a large number of gas hydrate samples with various occurrences, including massive, veins, laminated, nodular, and disseminated, were recovered from multiple gas hydrate-bearing layers within 220 mbsf at sites W05, W07, W08, W09, and W16 [85, 86]. The gas hydrates generally accumulated in the top strata with distinct leakage features in the gas chimney zone (Figures 7(b) and 7(c)). However, the cold seeps in the drilling area are currently inactive, and the seabed is covered by a large area of carbonate pavement and dead microbial communities [53]. Carbonate samples have also been obtained via drilling and coring of the GHSZ, indicating that gas hydrate dissociation accompanied the cold seep in geological history [94]. In addition, an active cold seep with distinct gas seepage and microbial communities has been discovered at Site F southwest of Taiwan, and exposed gas hydrates were found on the seafloor $[47,48,53]$. In plan view, most of the active and inactive cold seeps are located within the distribution area of the BSR (Figure 1). There is also an obvious connection between the gas hydrates and the seafloor seepage, and the gas hydrates accumulated at the top of and/or on both sides of the vertical seepage pathways (Figure 7).

\section{Gas Hydrate System}

5.1. Gas-Bearing Fluid Migration. Through further studies in recent years, marine petroleum geological research and exploration has confirmed that the deep-water cold seeps, gas hydrate accumulations, and associated seismic anomalies, including BSRs, in the northern SCS are closely related to the gas-bearing fluid migration pathways, which are controlled by the tectonic and sedimentary conditions. A gas hydrate system is genetically related to the focused fluid flow and seepage systems composed of mud diapirs, mud volcanoes, gas chimneys, pipes, and faults in the different regions $[49,53,76-78,80,85,121,123,124]$.

The drilling sites of expeditions GMGS1, GMGS3, and GMGS4 in the Shenhu area were located on the top of gas chimneys or mud diapirs, which provided the pathways by which the deep gas-bearing fluids could migrate into the shallow strata and transported the thermogenic gas generated by the Paleogene source rocks and the shallow biogenic gas in the Baiyun Sag to the GHSZ to form gas hydrates $[112,113]$. At the drilling sites from which high saturation gas hydrates $(\sim 60 \%)$ were recovered through pressure coring, such as sites W18 and W19, the gas-bearing fluids migrated upward from the deep Paleogene strata along large-scale mud diapirs and gas chimneys, resulting in large fuzzy seismic zones on the seismic profiles [77]. In plan view, the development range of the diapirs and gas chimney has a very obvious relationship with the distribution of the BSR and the gas hydrate accumulations, which are mainly distributed along the ridge (Figure 9). This demonstrates that the migration pathways of these gas-bearing fluids controlled the gas hydrate accumulation in the Shenhu area $[104,112,113]$. Based on the high-resolution 3D seismic data, it was found that there are also large, deep faults in the Shenhu area that connect the Paleogene source rocks and the shallow GHSZ, which also serve as vertical pathways for fluid migration, especially the thermogenic gas derived from the deep source rocks $[104,112]$. Within the GHSZ, due to sediment gliding and/or slope failure, some of the gas hydrate-bearing strata have formed slump faults, which connect the base of the GHSZ with the seafloor, constituting pathways by which the gas entering the GHSZ can move further upward, and some of the gas may leak out of the sea floor after the dissociation of the gas hydrates, producing upward fluid migration. Additionally, the gas-bearing fluids commonly migrate along the preexisting slump faults developed above the BGHSZ, and this fluid escape may in turn cause seafloor collapse and gas hydrate dissociation.

Medium-strong seafloor gas seepage is occurring in the deep-water Qiongdongnan Basin, and a large number of seepage pathways related to gas hydrate formation and accumulation have developed, including mud diapirs, gas chimneys, and faults of variable scales $[77,78]$. The distribution of the BSR indicates that the occurrence of the gas hydrates has a direct vertical and planar superposition relationship with these fluid activities [77]. Most significantly, the seismic reflections below the Haima Cold Seep discovered in 2015 are chaotic, creating a large fuzzy zone due to the migration of deep gases into the shallow strata. In addition, several faults and fractures have been identified within the cold seep area, constituting vertical pathways for deep fluid migration and seepage [49, 121]. In 2018 and 2019, massive gas hydrate samples were successfully obtained from a large gas chimney development area in the eastern Qiongdongnan Basin [51, 76, 82]. Seismic interpretation and gas hydrate drilling have demonstrated that this gas hydrate accumulation is closely related to the underlying gas chimneys and deeply buried low uplift. The large faults developed on both sides of the uplift directly connect the deep source kitchens with the vertical gas chimneys and the GHSZ, acting as thermogenic hydrocarbon migration pathways $[76,125]$.

Since the Late Miocene, Neotectonic activity has occurred in the cold seep and gas hydrate accumulation area 
in the Dongsha area. A large number of gas chimneys, mud diapirs, and mud volcanos, which act as gas-bearing fluid migration pathways, have developed in this area. In particular, clusters of gas chimneys have been identified on the seismic profiles in the GMGS2 gas hydrate drilling area [53, 64]. Another type of hydrocarbon migration pathway in the Dongsha drilling area is faults, which are mainly inherited faults and small active faults on the top and/or flanks of the large gas chimneys, and some of the inherited faults extend downward into the deeply buried basement. The fault development is usually accompanied by gas chimneys or is located directly inside the gas chimneys. These faults have been active since the Late Miocene and are mainly distributed in the western ridge in the drilling area. However, the faults developed in the eastern ridge are less abundant and are smaller in size (Figure 7). Most of the identified faults are subvertical and steeply dipping and developed from the Late Miocene to the Quaternary. Some of these faults even reach the seafloor. Many of the faults developed on the top and/or flanks of the gas chimney are steep in occurrence, small in size, and variable in strike. They often cut the BSR and are associated with enhanced reflections, which are the result of the upward migrated hydrocarbons along the gas chimneys and deep large-scale faults. When the gas flux is sufficient, gas hydrates will form and accumulate in the GHSZ. In addition, the gas hydrate accumulation area corresponds well with the strike of the faults and the extension direction of the gas chimneys (Figure 7) [85]. The gas hydrate drilling and coring sites in the Dongsha area are basically located near the fault at the top of a gas chimney (Figure 7). The successful recovery of fracture-filling gas hydrates indicates that the highly efficient fluid migration system composed of faults and gas chimneys enabled high flux gas-bearing fluid migration and gas hydrate accumulation in the Dongsha area, and it also controlled the formation, accumulation, and distribution of the gas hydrates [110].

In the eastern Dongsha area, the mud volcanoes and mud diapirs near the BSRs are well developed in the Taixinan Basin, indicating that they constitute the pathways for the migration of the deep gas-bearing fluids needed for gas hydrate formation [97]. Gas chimneys, pipe structures, and unconformities, which constitute the pathways by which the gas-bearing fluids migrate into the GHSZ, have also been observed in this area (Figure 8). Based on the seismic profile crossing the Site F (Formosa ridge) cold seep in the Taixinan Basin, the gas chimneys that constitute the migration pathway by which the deep gas leaks into the seabed and forms a cold seep were identified $[53,124]$. In addition, mud diapirs and gas chimneys that directly connect the BSR with the seabed and constitute gas migration and leakage pathways were also identified in Pointer Ridge in the Taixinan Basin, forming cold seeps and gas plumes on the seabed [126, 127].

Although the majority of the gas seeps discovered in the northern SCS are related to preexisting pathways composed of faults, gas chimneys, and mud diapirs, there are gas seeps that formed due to the behavior of the gases themselves. Many high-resolution seismic profiles exhibit indicators of the presence of shallow gas seeps in the Quaternary sediments in the northern SCS, such as pipe structures, bright spots, seabed mounds, and pockmarks (Figures 3 and 4). These subsurface gas seepage/leakage areas are probably caused by gas hydrate dissociation and have nothing to do with the existing deep faults and mud diapirs.

5.2. Types and Origin of the Hydrate Gases. The formation and activity of the cold seep system are accompanied by a large number of substances, including water, gas, various chemicals, and sediments, that leak from the deep strata into the seabed. The migration and supply of gas-bearing fluids provide the material basis for cold seep activity and gas hydrate accumulation. The source and origin of hydrate gas also affect the development scale of cold seeps and gas hydrate reservoirs. The genetic types and potential source rocks of the hydrate gas in the cold seep areas in the northern SCS have been basically characterized through submarine ROV Laser Raman in situ surveys, seabed and subsurface sampling, and geochemical analyses of gas hydrate samples [50, 128-133].

The hydrate gas samples from the shallow surface of the Haima Cold Seep in the Qiongdongnan Basin in the western SCS reveal that methane is the main component, with a concentration of $>99.5 \%$, while ethane and propane are typically present in very low concentrations. Most of the carbon isotope values of the methane are lighter than $-60 \%$. The plot of the carbon $\left(\delta^{13} C_{1}\right)$ and hydrogen $(\delta D)$ isotope values of the methane indicates that the hydrate gas is a mixture of biogenic gas and thermogenic gas, with a bias toward biogenic gas. The carbon isotopes of the ethane range from $-25.5 \%$ o to $-26.8 \%$ o [50]. The geochemical composition and isotopic characteristics of the hydrate gas indicate that in addition to the shallow biogenic gas supply for gas hydrate formation, deep mature thermogenic gas also contributed to the gas hydrate formation and accumulation [50, 77]. In 2018, the GMGS5 expedition carried out deep drilling in the cold seep area in the eastern Qiongdongnan Basin to recovery gas hydrate samples. The geochemical analysis results revealed that the hydrate gas contains up to $20 \% \mathrm{C}_{2}$ + hydrocarbon gas $[76,134]$. The $\delta^{13} \mathrm{C}$ and $\delta \mathrm{D}$ values of the methane indicate that the hydrate gas has a mixed genetic origin but predominantly thermogenic gas [125]. In addition, through comparative analysis of the genesis of the shallow hydrate gas and deep conventional natural gas, it has been concluded that there is a close genetic relationship between shallow gas hydrate reservoirs, deep source rocks, and conventional petroleum reservoirs [76]. During the vertical long-distance migration, deep thermogenic gas may undergo microbial degradation and transformation to form secondary microbial methane [125, 134], which together with the shallow biogenic gas supply sufficient material for gas hydrate formation. In general, the cold seep activity and gas hydrate accumulation in the Qiongdongnan Basin are supplied by both biogenic and thermogenic gases (Figure 10).

The samples obtained during gas hydrate drilling in the Shenhu area reveal that the genesis of the hydrate gas varies 


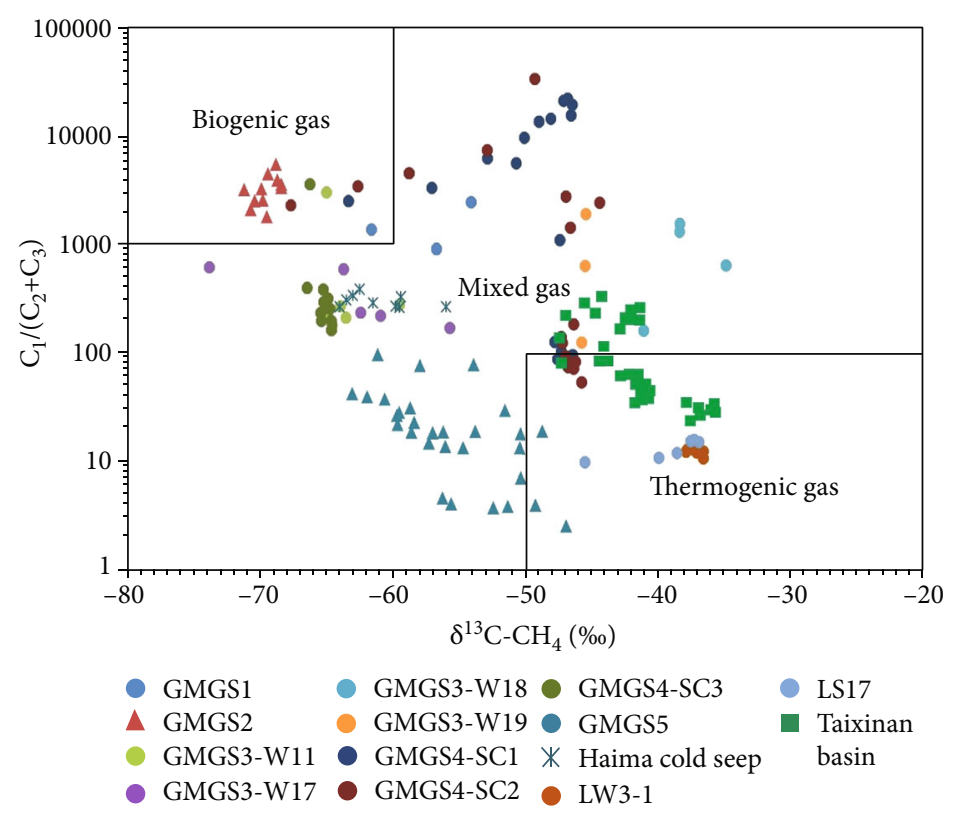

Figure 10: Genetic types of the hydrate gases associated with the cold seep system and conventional gas recovered from deep gas reservoirs in the Pearl River Mouth Basin (LW3-1) and the Qiongdongnan Basin (LS17) in the northern South China Sea. The GMGS 1, 2, 3, 4, and 5 hydrate gas data are from Su et al. [74], Zhang et al. [132], Zhang et al. [134], and Sha et al. [141]. The Haima Cold Seep hydrate gas data are from Minshull et al. [50]. The conventional gas data for LW3-1 and LS17 are from Dai et al. [131] and Zhang et al. [155]. The hydrocarbon data for the Taixinan Basin are from Chen et al. [144].

greatly among the different sampling sites. The methane concentrations of the hydrate gas obtained at sites $\mathrm{SH} 2$, SH3, and SH7 during the GMGS1 drilling expedition in 2007 were $>99.9 \%$, and most of the carbon isotope values of the methane were lighter than $-55 \%$, indicating biogenic gas $[129,135,136]$. However, it is believed that thermogenic gas also contributed to the gas hydrate accumulation based on analysis of the $\delta^{13} \mathrm{C}_{1}$ and $\delta \mathrm{D}$ values of the methane and the geological characteristics of the gas hydrate accumulation [74]. According to the results of drilling expedition GMGS3 at sites W11 and W17 in 2015, the methane concentration of the hydrate gas is dominant, and the $\delta^{13} \mathrm{C}_{1}$ values are basically lighter than $-60 \%$, indicating microbial gas, while the $\delta^{13} \mathrm{C}_{1}$ values of the hydrate gas from sites W18 and W19 are greater than -50\%o, suggesting thermogenic gas [132]. The geochemical analysis of the hydrate gas collected from the first gas hydrate production site in the Shenhu area reveals that the hydrate gas is a mixture of biogenic and thermogenic gases [137]. In general, the hydrate gas in the Shenhu area is sourced by a mixture of biogenic gas and thermogenic gas $[119,132]$, but most of the areas are dominated by biogenic gas (Figure 10). In addition, similar to the Qiongdongnan Basin, the source of the thermogenic gas in the gas hydrate reservoir in the Shenhu area is closely related to the deep gas reservoirs [132, 138]. The genetic type of the thermogenic gas in the confirmed gas hydrate reservoir in the Shenhu area is similar to the gas in the deep conventional reservoirs, such as LW3-1, PY30-1, and PY35-1, which is derived from the hydrocarbon generation supply of the mature Paleogene source rocks in the Baiyun Sag [81, 132, 139, 140].
The methane concentration of the hydrate gas obtained during expedition GMGS2 in the Dongsha area is 96.599.8\%, and no $\mathrm{C}_{2}+$ hydrocarbons were detected. The $\delta^{13} \mathrm{C}_{1}$ values of the methane are $-68.4 \%$ o to $-71.2 \%$, and the $\delta \mathrm{D}$ values are $-182 \%$ to $-184 \%$, suggesting a biogenic origin (Figure 10) [141]. Although the genesis of hydrate gas obtained from several drilling sites indicates that only biogenic gas contributed to the formation of the gas hydrates, some researchers believe that thermogenic gas that is closely related to the deep petroleum reservoirs contributed to the formation of the gas hydrates in the Dongsha area based on analysis of the biomarkers of the organic matter in the gas hydrate-bearing sediments [142, 143]. Nevertheless, the deep petroleum reservoirs in this area have not been confirmed in any commercial borehole. In situ Laser Raman probing and testing in the Taixinan Basin have shown that there is a large amount of methane gas in the gas hydrates accumulated in the shallow cold seep area $[47,48]$. In addition, geochemical studies of the hydrocarbons collected from the mud volcano development area show that the $\delta^{13} \mathrm{C}_{1}$ values range from $-103 \%$ o to $-35.6 \%$, and most of the values are greater than $-50 \%$, indicating that the hydrate gases are a mixture of biogenic and thermogenic gases, with a bias toward thermogenic gas. This also indicates the contribution of deep mature source rocks to the gas hydrate accumulation [130, 144].

\section{Discussion}

6.1. Relationship between Gas-Bearing Fluids and the Seafloor Morphology of the Cold Seep. Submarine gas seepage 
and/or leakage can greatly change the seabed's topography, forming pockmarks, authigenic carbonate crusts, mounds, domes, mud volcanoes, and other microgeomorphic features $[15,27,40,57,60,61,63,64,115,145,146]$. In addition, chemosynthesis-based communities, unique cold seep carbonate minerals, and the occurrence of gas hydrates are frequently encountered in the cold seep development area. Multiple seafloor geomorphic features have been identified in the distribution areas of cold seeps and their associated gas hydrate accumulations in the northern SCS, indicating a strong connection between deep fluid activities and the shaping of the seafloor's topography and geomorphic features.

In area containing cold seeps and gas hydrate accumulations in the Qiongdongnan Basin, biogenic gas and deep thermogenic gas dominated by methane migrated to and gathered in the shallow strata through migration and seepage pathways, including faults, pipes, diapirs, and gas chimneys, and leaked into the seabed to form cold seeps $[49,77$, $121,123,147-149]$. The rapid migration and flow of gasbearing fluids often produce bubbling plumes or gas flames on the seafloor. Rapid and abrupt fluxes of gas and water create craters and/or pockmarks in the seabed [150]. Smaller pockmarks may be the result of deep fluid seepage, which can be directly observed on seismic profiles. The high-flux gases and/or liquid hydrocarbons in the Haima Cold Seep region cause strong gas plumes hundreds of meters high [77]. The medium flux fluids can form gas hydrates in the subsurface sediments and even form gas hydrate mounds and accompanying chemosynthetic communities [40], which were verified by the ROV observations in 2018 on the seafloor in the gas hydrate drilling area in the eastern part of the Haima Cold Seep [122, 149]. The corresponding relationship between fluid activities with variable fluxes and the seafloor geomorphology have been observed in the deep-water Qiongdongnan Basin, indicating that the intensity of the deep fluid activities in the different regions of the basin is diverse, which is very similar to the cold seep and associated gas hydrate accumulation area in the Gulf of Mexico [57].

Massive pavements and/or patches of carbonate crust on the seafloor have been discovered in the gas hydrate drilling area in the Dongsha area $[151,152]$. The formation of these seafloor deposits was related to the paleo-cold seep plumbing systems composed of deep gas chimneys and faults. It has been proposed that the formation of carbonate crusts is related to the large-scale dissociation of gas hydrates in the past $\sim 30-40 \mathrm{ka}[93,151,152]$. The current cold seep fluid activity in the Dongsha gas hydrate drilling area is weak, so it is hard to find active cold seep vents, gas leakage, and biological communities on the seabed. However, in cold seep development areas such as Site F in the central-eastern Taixinan Basin, there are distinct seepage pathways and/or seabed mounds on the seismic profiles, and seabed mounds, mud volcanoes, and pockmarks have been clearly observed through seabed observations $[53,83,124]$. There are abundant microbial communities associated with the cold seep system, and gas leakage and massive gas hydrates have been directly observed on the seafloor, indicating that some of the gas hydrates are decomposing. In addition, mud diapirs and mud volcanoes are commonly developed in the Taixinan Basin and are usually accompanied by strong gas-bearing fluid activity. A large amount of deep gas migrated into the GHSZ through the mud diapirs and precipitated as gas hydrates. These phenomena indicate that the gas-bearing fluid activity in the Dongsha area is weak-medium at present, but it may have been very vigorous for a long time during the past hundreds of thousands of years. In contrast, the gas-bearing fluid activity in the Taixinan Basin is relatively intense at present.

Biogenic gas generated by microorganisms in the shallow strata can only be diffused in situ or in unconsolidated porous sediments within a limited distance, and it can be enriched in the GHSZ under high pressure and low temperature conditions through low flux seepage and diffusion with a to form gas hydrates [153]. In general, the intensity of the active gas-bearing fluids in the diffusion-dominated areas is extremely weak. Drilling and coring have demonstrated that a large amount of microbial gas is generated in situ and is diffused within a short distance to form widely distributed pore-filling gas hydrates in the Shenhu area [87-91]. Although geophysical and geochemical evidence has demonstrated the contribution of thermogenic gas to the formation and accumulation of the gas hydrates in the Shenhu area [74, $132,138,154]$, the gas supply was limited and may be restricted to the area in the vicinity of gas field LW3-1. In general, due to the weak gas-bearing fluid flux, seafloor seepage is seldom observed, and there are hardly any seafloor cold seep system and associated seafloor authigenic carbonate pavements. Additionally, evidence of a paleocold seep has been found in the Shenhu area, indicating that the dissociation of gas hydrates and gas seepage occurred in the past.

Based on the above discussion of the seafloor morphology, the associated gas-bearing fluid activity in the cold seep system, and the associated gas hydrate systems confirmed in the Qiongdongnan Basin, the Shenhu area, the Dongsha area, and the Taixinan Basin, it is reasonable to conclude that the seafloor morphology of cold seeps is controlled by the intensity of the active deep gas-bearing fluids in the northern slope of the SCS. Therefore, observing and studying the submarine geomorphology and the development characteristics of the gas-bearing fluid and associated microbial communities in a cold seep system are of great significance to gas hydrate exploration.

6.2. Deep-Shallow Coupling of Gas Hydrates, Cold Seeps, and Deep Petroleum Reservoirs. From the above analysis of the origin of cold seep-associated hydrate gas, it was found that hydrate-bound gas, especially thermogenic gas, has a very close genetic relationship with the deep source rocks and/or petroleum reservoirs. The seismic profiles crossing cold seeps and gas hydrate accumulation areas also show that deep gas-bearing fluids can be transported through multiple pathways into the GHSZ to precipitate as gas hydrates or to leak out onto the seabed and form cold seeps.

The cold seeps in the Qiongdongnan Basin are developed on the top of the strata overlying the low uplift of the 
pre-Paleogene basement, which resulted from intense magmatic intrusion $[84,123,138]$. In addition, the faults and fractures formed by the uplift of structures led to the generation of active plumping systems $[84,123]$ connected to the deep Paleogene source rocks, transporting deep hydrocarbons upward and resulting in the formation of gas chimneys and associated fluid leakage under the overpressure. Plenty of thermogenic and biogenic gas migrated along these gas chimneys into the GHSZ to form fracture-filling gas hydrates in mass transport deposits (MTDs) [76]. Analysis of the gas hydrate petroleum system revealed the close relationship between the shallow gas hydrates and deep conventional petroleum reservoirs. As can be seen from the seismic profiles (Figure 5), the deep central channel sand gas reservoir and the deep source strata have a direct vertical coupling relationship with the distribution of the gas hydrates. The geochemical characteristics of the gas hydrates drilled during expedition GMGS5 indicate that the thermogenic gas in the shallow gas hydrate accumulation area is consistent with the origin of the natural gas in deep reservoirs such as LS17-2, LS22-1, and Y8-1 [125, 155, 156]. Therefore, it is believed that the shallow gas hydrates are homologous with the deep gas reservoirs. The gas-bearing fluid provided by the development and evolution of the source rocks in the deep depression, the migration system composed of the low uplift caused by the tectonic activity, the associated faults, and the gas chimneys jointly controlled the formation of the submarine cold seep system and the gas hydrate accumulation in the Qiongdongnan Basin.

The hydrate gas recovered from several coring sites in the Shenhu area was supplied by thermogenic gas, which is also related to the deep oil and gas reservoirs [132, 138]. The large-scale mud diapirs and gas chimneys originate in the Paleogene strata and act as migration pathways connecting the thermogenic gas kitchens with the GHSZ (Figure 9). The elements of the gas hydrate system are consistent in all of the gas hydrate accumulation reservoirs in the Shenhu area $[104,132,138]$. In addition, the higher the gas hydrate saturation, the better the spatial matching relationship between the gas source, migration pathways, and GHSZ $[80,104]$. Acoustic chaotic reflections resulting from mud diapirs and gas chimneys have been identified below the BSR at sites W18 and W19 in the GMGS3 drilling area where gas hydrates with $>60 \%$ saturation have been recovered. Upward gas-bearing fluid migration and charging controlled the formation of the high saturation gas hydrates [80, $81,104]$. Additionally, high angle faults have been identified immediately below the high saturation gas hydrate reservoirs (BSRs) in sites W11 and W17 [80]. In the deeper area, there is a deep-shallow coupling relationship between the shallow gas hydrates and the deep petroleum reservoirs, with gas chimneys, mud diapirs, and high angle faults directly connecting the deep reservoirs and the shallow GHSZ [104]. For example, the deep thermogenic gas in gas field LW3-1 was transported to the GHSZ by large faults and mud diapirs to form high saturation gas hydrates [138], which has been confirmed by the isotopic compositions of the hydrate gas and conventional gas in the Baiyun Sag $[119,132,138]$. Therefore, the effective coupling of the deep gas source, the migration pathways, and the GHSZ promoted the migration and accumulation of high saturation gas hydrates in the Shenhu area.

There are cold seeps with variable active intensities and associated gas hydrate accumulation in the Dongsha area. However, the direct evidence obtained from geochemical analysis of the available recovered hydrate gas samples indicates that the hydrate gas is microbial in origin and has nothing to do with the deep source rocks. In addition, thus far, no commercial conventional oil and gas reservoirs have been discovered in the Dongsha area, making it more difficult to prove the relationship between the shallow gas hydrates and the deep petroleum reservoirs. However, recent basin modeling and geochemical studies have shown that deep source rocks and possible oil and gas reservoirs may contribute to the formation of shallow gas hydrates [142, 143]. In addition, thermogenic gas associated with mud volcanos has been detected in the nearby central-eastern Taixinan Basin, suggesting a potential coupling relationship between the shallow gas hydrates and the potential deep petroleum reservoir $[130,144]$.

Based on the above discussion, it is believed that there is a deep-shallow coupling relationship between the cold seep system, the gas hydrate reservoir, and the deep petroleum reservoirs in the northern slope of the SCS. It is reasonable to conclude that the deep petroleum system and the gasbearing fluid migration system jointly controlled the development of the submarine cold seep system and the enrichment of the gas hydrate accumulation in the northern SCS.

6.3. Significance for Gas Hydrate Exploration. The geological, geophysical, and occurrence characteristics of cold seep systems and gas hydrate systems in different regions of the northern SCS can be characterized by analyzing the geological and geomorphological characteristics of the cold seep systems based on submarine image data obtained from submarine observations, deep penetrating seismic and subbottom profiles, and gas hydrate drilling and coring information. Both diffusive type (pore filling dominated) and leakage type (fracture filling dominated) gas hydrates associated with cold seep systems have been confirmed and recovered in the northern slope of the SCS $[49,51,53,76,80,81$, $85-91,112,120]$. The gas hydrates in the Shenhu area are diffusive type with a pore-filling occurrence, and they are mainly accumulated in sediments dominated by clayey silt. The gas hydrates in the Qiongdongnan Basin are mainly leakage type and are mainly present as fracture-filling hydrates, while both fracture-filling and pore-filling gas hydrates have been discovered in the same drilling site at different depths in the Dongsha area. Therefore, there are significant differences in the accumulation and occurrence characteristics of the gas hydrates in different regions. Gas hydrate drillings in the Shenhu area, the Dongsha area, and the Qiongdongnan Basin have revealed that the gas hydrate-bearing sediments are mainly clayey silt and silty clay with little difference in lithology. From the perspective of the differences in the development of the cold seep systems, the intensity of the activity of the gas-bearing fluids, the types of gas migration pathways, and the deep-shallow 
coupling relationship between the GHSZ and the deeply buried source rocks may jointly control the differences in the gas hydrate occurrences and accumulation types.

The methane in the pore filling gas hydrates was mainly derived from the strata in the vicinity of the GHSZ. The methane flux was limited, and it is normally in the dissolved state in the pore water [157]. The gas migrated over a short distance through the pores, fractures, and faults. When the concentration of methane dissolved in the pore water exceeds the thermodynamic equilibrium saturation solubility of the two-phase water-hydrate system, the dissolved methane precipitates to form gas hydrates immediately at the BGHSZ [158]. However, hardly any cold seeps have been observed in the areas with abundant pore-filling gas hydrates due to the relatively low gas-bearing fluid flux and impermeable gas hydrate-bearing sediments. The drilling results have shown that there is a good correspondence between the distribution of the gas hydrates and the BSR in the Shenhu area. The BSR is mainly distributed in the submarine ridge and at the position where the ridge dips into the deep sea plain [80, $103,104]$. In addition, the distribution of the BSR has a good spatial overlap relationship with the development and distribution areas of the mud diapirs and gas chimneys, indicating that the gas migration conditions may have controlled the distribution of the gas hydrates. However, although the mud diapirs and gas chimneys extend upward from the deep strata, they may have had a limited effect on the migration of the deep thermogenic gas, and only a small part of the thermogenic gas may have migrated to the GHSZ to precipitate as gas hydrates. Therefore, the slow diffusion of the shallow biogenic gas and the limited migration of thermogenic gas derived from the deep strata controlled the pore filling gas hydrates in the Shenhu area.

The leakage type gas hydrates supplied by both biogenic gas and thermogenic gas recovered or speculated in the Qiondongnan Basin, the Dongsha area, and the centraleastern Taxinan Basin in the northern SCS indicate that medium-high flux methane migration to the seafloor via free gas leakage and/or seepage along faults, gas chimneys, pipes, mud volcanoes, and mud diapirs controlled the hydrocarbon migration and gas hydrate accumulation. When gas seeped and/or leaked out to the seabed due to a high fluid flux, it is likely to result in geomorphological features such as pockmarks and mounds, and cold seep microbial communities develop. Additionally, through the metabolic processes of autotrophic biota, authigenic carbonate rocks are prone to precipitate. Therefore, the seafloor microtopography and outcrops of carbonate rocks in cold seep systems in deep water areas are important indicators of the occurrence of leakage type gas hydrates. The leakage type gas hydrate enrichment areas with a similar origin discovered by drilling around the world include the North Cascadia Hydrate Ridge in the western continental margin of the United States [26, 151], the Gulf of Mexico [159, 160], the K-G Basin offshore of India [161], and the Ulleung Basin in South Korea [109, 162]. Therefore, based on comprehensive analysis of seismic, subbottom, and multibeam data, analysis of the tectonic activities and investigation of the geological and geomorphic characteristics of the seabed in areas where gas-bearing fluid migration system has developed are the main approaches to exploring active cold seeps and leakage type gas hydrate systems [163-167].

Generally, the cold seep systems and their associated gas hydrate accumulations in the northern slope of the SCS have been found to have a close relationship with the deep source rocks and/or petroleum reservoirs through multiple gas-bearing fluid migration pathways. It is also reasonable to propose that conventional oil and gas and gas hydrates are paragenetic in petroliferous basins. Therefore, conventional oil and gas reservoirs and favorable hydrocarbon accumulation areas are also favorable gas hydrate exploration targets. The discovery of a cold seep system is also an important indicator of gas hydrate occurrence in the SCS, and more in situ geophysical investigations and deep drilling are needed. We look forward to the significant discovery of gas hydrate-associated cold seep systems and the advancement of our knowledge of them in the SCS.

\section{Conclusions}

(1) Cold seep systems with diverse microgeomorphologies and geological and geochemical features are related to the intensity of the activity of gas-bearing fluids in the northern South China Sea. The activity of the cold seeps in the Qiongdongnan Basin is medium-strong, with abundant gas seepage, plumes, and microbial communities. The active cold seeps in the Dongsha area and the Taixinan Basin are similar to those in the Qiongdongnan Basin, exhibiting a medium-high fluid flux. In addition, the widespread authigenic carbonate pavements in some paleo-cold seeps are related to the dissociation of gas hydrates and cessation of seepage. The fluid activity in the Shenhu area is weak at present, and there is almost no submarine leakage

(2) The cold seep systems in the northern South China Sea are generally connected with the deep strata through a variety of gas-bearing fluid migration pathways, including mud diapirs, mud volcanoes, gas chimneys, and faults. They are a precondition for the formation of a cold seep, and they also control the differential development of cold seep systems

(3) The activity of the cold seeps in the northern South China Sea is closely related to the formation and accumulation of gas hydrates, which are usually precipitated in cold seep vents and vertical fluid migration pathways, indicating that the formation of gas hydrates is controlled by the activity of gas-bearing fluid

(4) The hydrocarbons recovered from cold seep systems and their associated gas hydrate accumulations in the northern South China Sea are generally mixtures of biogenic gas and thermogenic gas, which are related to the deep mature source rocks and petroleum reservoirs 
(5) In the northern South China Sea, there is a deepshallow coupling relationship between the cold seep systems, gas hydrate accumulations, and deep petroleum reservoirs. It is necessary to pay more attention to the favorable accumulation areas of conventional oil and gas with abnormal gas-bearing fluid activity in the later stages of the exploration of active cold seeps and their associated gas hydrates in the South China Sea

\section{Conflicts of Interest}

The authors declare that there is no conflict of interest regarding the publication of this paper.

\section{Acknowledgments}

This work was supported by the National Natural Science Foundation of China (no. 42076054, no. 41806071, and no. 41806074), the Guangdong Basic and Applied Basic Research Foundation (no. 2019B030302004), Key Special Project for Introduced Talents Team of Southern Marine Science and Engineering Guangdong Laboratory (Guangzhou) (no. GML2019ZD0102), and the China National Hydrate Project (no. DD20190217, no. DD20190218). The authors wish to thank those that contributed to the success of the China National Gas Hydrate Program Expeditions 1, $2,3,4,5$, and 6 .

\section{References}

[1] K. Olu, S. Lance, M. Sibuet, P. Henry, A. Fiala-Médioni, and A. Dinet, "Cold seep communities as indicators of fluid expulsion patterns through mud volcanoes seaward of the Barbados accretionary prism," Deep Sea Research Part I Oceanographic Research Papers, vol. 44, no. 5, pp. 811-841, 1997.

[2] H. Sahling, S. V. Galkin, A. Salyuk et al., "Depth-related structure and ecological significance of cold-seep communities- a case study from the Sea of Okhotsk," Deep Sea Research Part I: Oceanographic Research Papers, vol. 50, no. 12, pp. 1391-1409, 2003.

[3] A. R. Talukder, "Review of submarine cold seep plumbing systems: leakage to seepage and venting," Terra Nova, vol. 24, no. 4, pp. 255-272, 2012.

[4] A. Rahman Talukder, A. Ross, E. Crooke et al., "Natural hydrocarbon seepage on the continental slope to the east of Mississippi Canyon in the northern Gulf of Mexico," Geochemistry, Geophysics, Geosystems, vol. 14, no. 6, pp. 19401956, 2013.

[5] M. Römer, H. Sahling, T. Pape et al., "Methane fluxes and carbonate deposits at a cold seep area of the Central Nile Deep Sea Fan, Eastern Mediterranean Sea," Marine Geology, vol. 347, no. 3, pp. 27-42, 2014.

[6] D. Feng, J. W. Qiu, Y. Hu et al., "Cold seep systems in the South China Sea: an overview," Journal of Asian Earth Sciences, vol. 168, pp. 3-16, 2018.

[7] S. Sauer, W. L. Hong, H. Yao, A. Lepland, and J. Knies, "Methane transport and sources in an arctic deep-water cold seep offshore nw Svalbard (Vestnesa Ridge, $79^{\circ} \mathrm{N}$ ), " Deep Sea
Research Part I Oceanographic Research Papers, vol. 167, 2021.

[8] K. R. Buck and J. P. Barry, "Monterey bay cold seep infauna: quantitative comparison of bacterial mat meiofauna with non-seep control sites," Cahiers de Biologie Marine, vol. 39, no. 3, pp. 333-335, 1998.

[9] J. P. Werne, R. R. Haese, T. Zitter et al., "Life at cold seeps: a synthesis of biogeochemical and ecological data from Kazan mud volcano, eastern Mediterranean Sea," Chemical Geology, vol. 205, no. 3-4, pp. 367-390, 2004.

[10] T. Lösekann, A. Robador, H. Niemann, K. Knittel, A. Boetius, and N. Dubilier, "Endosymbioses between bacteria and deepsea siboglinid tubeworms from an arctic cold seep (Haakon Mosby mud volcano, Barents sea)," Environmental Microbiology, vol. 10, no. 12, 2008.

[11] O. Hélène, O. Karine, D. Stéphanie et al., "Geological and biological diversity of seeps in the Sea of Marmara," Deep Sea Research Part I: Oceanographic Research Papers, vol. 161, no. 9, article 103287, 2020.

[12] A. Khripounoff, J. C. Caprais, C. Decker, J. L. Bruchec, P. Noel, and B. Husson, "Respiration of bivalves from three different deep-sea areas: cold seeps, hydrothermal vents and organic carbon-rich sediments," Deep Sea Research Part II Topical Studies in Oceanography, vol. 142, pp. 233-243, 2017.

[13] L. L. Mazurenko and V. A. Soloviev, "Worldwide distribution of deep-water fluid venting and potential occurrences of gas hydrate accumulations," Geo-Marine Letters, vol. 23, no. 34, pp. 162-176, 2003.

[14] Y. Cao, D. Chen, and M. L. Cathles, "A kinetic model for the methane hydrate precipitated from venting gas at cold seep sites at Hydrate Ridge, Cascadia margin, Oregon," Journal of Geophysical Research Planets, vol. 118, no. 9, pp. 46694681, 2013.

[15] H. H. Roberts, D. Feng, and S. B. Joye, "Cold-seep carbonates of the middle and lower continental slope, northern Gulf of Mexico," Deep Sea Research Part II Topical Studies in Oceanography, vol. 57, no. 21-23, pp. 2040-2054, 2010.

[16] A. Crémière, G. Bayon, E. Ponzevera, and C. Pierre, "Paleoenvironmental controls on cold seep carbonate authigenesis in the Sea of Marmara," Earth and Planetary Science Letters, vol. 376, pp. 200-211, 2013.

[17] D. Feng and D. F. Chen, "Authigenic carbonates from an active cold seep of the northern South China Sea: new insights into fluid sources and past seepage activity," Deep sea research part II: topical studies in oceanography, vol. 122, pp. 74-83, 2015.

[18] S. A. Novikova, Y. F. Shnyukov, E. V. Sokol, O. A. Kozmenko, D. V. Semenova, and V. A. Kutny, "A methane-derived carbonate build-up at a cold seep on the Crimean slope, northwestern Black Sea," Marine Geology, vol. 363, pp. 160-173, 2015.

[19] I. R. MacDonald, N. L. Guinasso, Jr, R. Sassen, J. M. Brooks, L. Lee, and K. T. Scott, "Gas hydrate that breaches the sea floor on the continental slope of the Gulf of Mexico," Geology, vol. 22, no. 8, pp. 699-702, 1994.

[20] H. H. Roberts, B. A. Hardage, W. W. Shedd, and J. Hunt, "Seafloor reflectivity-an important seismic property for interpreting fluid/gas expulsion geology and the presence of gas hydrate," Leading Edge, vol. 25, no. 5, pp. 620-628, 2012.

[21] V. Thiel, J. Peckmann, H. H. Richnow, U. Luth, and W. Michaelis, "Biomarkers for anaerobic methane oxidation 
in black sea seep carbonates and a microbial mat," Marine Chemistry, vol. 73, no. 2, pp. 97-112, 2001.

[22] K. Olu-Le Roy, M. Sibuet, A. Fiala-Médioni et al., "Cold seep communities in the deep eastern Mediterranean Sea: composition, symbiosis and spatial distribution on mud volcanoes," Deep Sea Research Part I: Oceanographic Research Papers, vol. 51, no. 12, pp. 1915-1936, 2004.

[23] S. K. Heijs, S. S. D. Jaap, and L. J. Forney, "Characterization of a deep-sea microbial mat from an active cold seep at the Milano mud volcano in the Eastern Mediterranean Sea," FEMS microbiology ecology, vol. 54, no. 1, pp. 4756, 2010.

[24] M. F. Vardaro, I. R. MacDonald, L. C. Bender, and N. L. Guinasso, "Dynamic processes observed at a gas hydrate outcropping on the continental slope of the Gulf of Mexico," Geo-Marine Letters, vol. 26, no. 1, pp. 6-15, 2006.

[25] R. Boswell, T. S. Collett, M. Frye, B. Shedd, D. R. McConnell, and D. Shelander, "Subsurface gas hydrates in the northern Gulf of Mexico," Marine and Petroleum Geology, vol. 34, no. 1, pp. 4-30, 2012.

[26] G. Bohrmann, M. Ivanov, J. P. Foucher et al., "Mud volcanoes and gas hydrates in the Black Sea: new data from Dvurechenskii and Odessa mud volcanoes," Geo-Marine Letters, vol. 23, no. 3-4, pp. 239-249, 2003.

[27] X. Zhang, Z. du, Z. D. Luan et al., "In situ Raman detection of gas hydrates exposed on the seafloor of the South China Sea," Geochemistry, Geophysics, Geosystems, vol. 18, no. 10, pp. 3700-3713, 2017.

[28] X. Zhang, Z. du, R. Zheng et al., "Development of a new deepsea hybrid Raman insertion probe and its application to the geochemistry of hydrothermal vent and cold seep fluids," Deep Sea Research Part I: Oceanographic Research Papers, vol. 123, pp. 1-12, 2017.

[29] Q. Liang, Y. Hu, D. Feng et al., "Authigenic carbonates from newly discovered active cold seeps on the northwestern slope of the South China Sea: constraints on fluid sources, formation environments, and seepage dynamics," Deep Sea Research Part I: Oceanographic Research Papers, vol. 124, pp. 31-41, 2017.

[30] Y. Fang, J. Wei, H. Lu et al., "Chemical and structural characteristics of gas hydrates from the Haima cold seeps in the Qiongdongnan Basin of the South China Sea," Journal of Asian Earth Sciences, vol. 182, p. 103924, 2019.

[31] J. Ye, J. Wei, J. Liang, J. Lu, H. Lu, and W. Zhang, "Complex gas hydrate system in a gas chimney, South China Sea," Marine and Petroleum Geology, vol. 104, pp. 29-39, 2019.

[32] F. Chen, X. Wang, N. Li et al., "Gas hydrate dissociation during sea-level highstand inferred from U/Th dating of seep carbonate from the South China Sea," Geophysical Research Letters, vol. 46, no. 23, pp. 13928-13938, 2019.

[33] X. Wang, B. Liu, J. Qian et al., "Geophysical evidence for gas hydrate accumulation related to methane seepage in the Taixinan Basin, South China Sea," Journal of Asian Earth Sciences, vol. 168, pp. 27-37, 2018.

[34] K. Olu, A. Duperret, M. Sibuet, J. P. Foucher, and A. FialaMédioni, "Structure and distribution of cold seep communities along the Peruvian active margin:relationship to geological and fluid patterns," Marine Ecology Progress, vol. 132, no. $1-3$, pp. 109-125, 1996.
[35] M. Sibuet and K. Olule Roy, "Cold seep communities on continental margins: structure and quantitative distribution relative to geological and fluid venting patterns," in Ocean margin systems, pp. 235-251, Springer, Berlin, Heidelberg, 2002.

[36] M. E. Torres, J. Mcmanus, and C. A. Huh, "Fluid seepage along the San Clemente Fault scarp: basin-wide impact on barium cycling," Earth and Planetary Science Letters, vol. 203, no. 1, pp. 181-194, 2002.

[37] A. M. Tréhu, "Seismic and seafloor evidence for free gas, gas hydrates, and fluid seeps on the transform margin offshore Cape Mendocino," Journal of Geophysical Research: Solid Earth, vol. 108, no. B5, p. 2263, 2003.

[38] H. Shoji, Y. K. Jin, A. Obzhirov et al., "Methane hydrates and plumes in the sea of Okhotsk," Journal of Geography, vol. 118, no. 1, pp. 175-193, 2009.

[39] I. Klaucke, H. Sahling, W. Weinrebe et al., "Acoustic investigation of cold seeps offshore Georgia, eastern Black Sea," Marine Geology, vol. 231, no. 1-4, pp. 51-67, 2006.

[40] W. C. Ingram, S. R. Meyers, C. A. Brunner, and C. S. Martens, "Late Pleistocene-Holocene sedimentation surrounding an active seafloor gas- hydrate and cold-seep field on the Northern Gulf of Mexico Slope," Marine Geology, vol. 278, no. 1-4, pp. 43-53, 2010.

[41] J. E. Johnson, C. Goldfinger, and E. Suess, "Geophysical constraints on the surface distribution of authigenic carbonates across the Hydrate Ridge region, Cascadia margin," Marine Geology, vol. 202, no. 1-2, pp. 79-120, 2003.

[42] M. Loher, Y. Marcon, T. Pape et al., "Seafloor sealing, doming, and collapse associated with gas seeps and authigenic carbonate structures at Venere mud volcano, Central Mediterranean," Deep Sea Research Part I: Oceanographic Research Papers, vol. 137, pp. 76-96, 2018.

[43] C. Boyer, "Shale gas: a global resource," Oilfield Review, vol. 23, no. 3, pp. 28-39, 2011.

[44] F. Colosimo, R. Thomas, J. R. Lloyd et al., "Biogenic methane in shale gas and coal bed methane: a review of current knowledge and gaps," International Journal of Coal Geology, vol. 165, pp. 106-120, 2016.

[45] J. Xu, Z. Chen, and R. Li, "Impacts of pore size distribution on gas injection in intraformational water zones in oil sands reservoirs," Oil and Gas Science and Technology, vol. 75, no. 6, p. $75,2020$.

[46] T. S. Collett, A. H. Johnson, C. C. Knapp, and R. Boswell, "Natural gas hydrates," in Natural Gas Hydrates-Energy Resource Potential and Associated Geologic Hazards, pp. 146-219, GeoScienceWorld, 2009.

[47] K. A. Kvenvolden, "Gas hydrates as a potential energy resource-a review of their methane content," in The future of energy gases, USGS Prof Paper, 1993.

[48] A. Demirbas, "Methane gas hydrate: as a natural gas source," Green Energy and Technology, vol. 34, pp. 113-160, 2010.

[49] R. Matsumoto, B. J. Ryu, S. R. Lee et al., "Occurrence and exploration of gas hydrate in the marginal seas and continental margin of the Asia and Oceania region," Marine and Petroleum Geology, vol. 28, no. 10, pp. 1751-1767, 2011.

[50] T. Minshull, H. Marín-Moreno, P. Betlem et al., "Hydrate occurrence in Europe: a review of available evidence," Marine and Petroleum Geology, vol. 111, pp. 735-764, 2020.

[51] M. Kurihara, A. Sato, H. Ouchi et al., "Prediction of gas productivity from eastern Nankai Trough methane-hydrate 
reservoirs," in Proceedings of 2008 Offshore Technology Conference, Texas, USA, 2008.

[52] E. M. Myshakin, M. Gaddipati, K. Rose, and B. J. Anderson, "Numerical simulations of depressurization-induced gas production from gas hydrate reservoirs at the walker ridge 313 site, northern Gulf of Mexico," Marine and Petroleum Geology, vol. 34, no. 1, pp. 169-185, 2012.

[53] Y. Konno, A. Kato, J. Yoneda et al., "Numerical analysis of gas production potential from a gas-hydrate reservoir at Site NGHP-02-16, the Krishna-Godavari Basin, offshore Indiafeasibility of depressurization method for ultra-deepwater environment," Marine and Petroleum Geology, vol. 108, pp. 731-740, 2019.

[54] J. Yoneda, A. Masui, Y. Konno et al., "Mechanical properties of hydrate-bearing turbidite reservoir in the first gas production test site of the eastern Nankai Trough," Marine and Petroleum Geology, vol. 66, no. 2, pp. 471-486, 2015.

[55] J. F. Li, J. L. Ye, X. W. Qin et al., "The first offshore natural gas hydrate production test in South China Sea," China Geology, vol. 1, no. 1, pp. 5-16, 2018.

[56] Y. E. Jianliang, Q. I. Xuwen, X. I. Wenwei et al., "Main progress of the second gas hydrate trial production in the South China Sea," Geology in China, vol. 47, no. 3, pp. 557-568, 2020.

[57] R. Sassen, H. H. Roberts, R. Carney et al., "Free hydrocarbon gas, gas hydrate, and authigenic minerals in chemosynthetic communities of the northern Gulf of Mexico continental slope: relation to microbial processes," Chemical Geology, vol. 205, no. 3-4, pp. 195-217, 2004.

[58] R. MATSUMOTO, Y. OKUDA, A. HIRUTA et al., "Formation and collapse of gas hydrate deposits in high methane flux area of the Joetsu basin, eastern margin of Japan Sea," Journal of Geography, vol. 118, no. 1, pp. 43-71, 2009.

[59] H. Cui, X. Su, F. Chen et al., "Microbial diversity of two cold seep systems in gas hydrate-bearing sediments in the South China Sea," Marine Environmental Research, vol. 144, pp. 230-239, 2019.

[60] P. V. Rensbergen, M. D. Batist, J. Klerkx, R. Hus, and P. Krinitsky, "Sublacustrine mud volcanoes and methane seeps caused by dissociation of gas hydrates in Lake Baikal," Geology, vol. 30, no. 7, 2002.

[61] J. R. Hein, W. R. Normark, B. R. Mcintyre, T. D. Lorenson, and C. L. Powell, "Methanogenic calcite, 13cdepleted bivalve shells, and gas hydrate from a mud volcano offshore southern California," Geology, vol. 34, no. 2, pp. 109-112, 2006.

[62] S. C. Chen, S. K. Hsu, C. H. Tsai, C. Y. Ku, and Y. Y. Wang, "Gas seepage, pockmarks and mud volcanoes in the near shore of sw Taiwan," Marine Geophysical Research, vol. 31, no. 1-2, pp. 133-147, 2010.

[63] J. Wei, T. Pape, N. Sultan et al., "Gas hydrate distributions in sediments of pockmarks from the Nigerian margin - results and interpretation from shallow drilling," Marine and Petroleum Geology, vol. 59, pp. 359-370, 2015.

[64] T. Wu, J. Wei, S. Liu et al., "Characteristics and formation mechanism of seafloor domes on the north-eastern continental slope of theSouth China Sea," Geological Journal, vol. 55, no. 1, pp. 1-10, 2020.

[65] T. Zander, I. Klaucke, J. Bialas, C. Berndt, D. Klaeschen, and C. Papenberg, Are cold seep locations controlled by topographic or gas hydrate distribution? A view from the Kerch seep plumbing system in the Black Sea, Gas in Marine Sediments (GIMS12), Taipei, Taiwania, 2014.

[66] R. Sassen, S. T. Sweet, A. V. Milkov, D. A. DeFreitas, and M. C. Kennicutt II, "Thermogenic vent gas and gas hydrate in the Gulf of Mexico slope: is gas hydrate decomposition significant?," Geology, vol. 29, no. 2, p. 107, 2001.

[67] G. D. Ginsburg and V. A. Soloviev, "Mud volcano gas hydrates in the Caspian Sea," Bulletin of the Geological Society of Denmark, vol. 41, no. 6, pp. 95-100, 1994.

[68] J. Greinert, K. Faure, L. Naudts et al., "An overview of gas hydrate and cold seep research along the Hikurangi margin, New Zealand (2006 and 2007)," Geophysical Research Abstracts, vol. 11, no. EGU2009-8588, 2009.

[69] A. Krabbenhoeft, J. Bialas, I. Klaucke, G. Crutchley, C. Papenberg, and G. L. Netzeband, "Patterns of subsurface fluid-flow at cold seeps: the Hikurangi margin, offshore New Zealand," Marine and Petroleum Geology, vol. 39, no. 1, pp. 59-73, 2013.

[70] T. Uchida, H. Lu, and H. Tomaru, "Subsurface occurrence of natural gas hydrate in the Nankai Trough area: implication for gas hydrate concentration," Resource Geology, vol. 54, no. 1, pp. 35-44, 2004.

[71] F. Colwell, R. Matsumoto, and D. Reed, "A review of the gas hydrates, geology, and biology of the Nankai Trough," Chemical Geology, vol. 205, no. 3-4, pp. 391-404, 2004.

[72] J. M. Brooks, H. B. Cox, W. R. Bryant, M. C. Kennicutt II, R. G. Mann, and T. J. McDonald, "Association of gas hydrates and oil seepage in the Gulf of Mexico," Organic Geochemistry, vol. 10, no. 1-3, pp. 221-234, 1986.

[73] J. He, S. Wang, W. Zhang, W. Yan, and Z. Lu, "Characteristics of mud diapirs and mud volcanoes and their relationship to oil and gas migration and accumulation in a marginal basin of the northern South China Sea," Environmental Earth Sciences, vol. 75, no. 15, 2016.

[74] M. Su, R. Yang, H. Wang et al., "Gas hydrates distribution in the Shenhu Area, northern South China Sea: comparisons between the eight drilling sites with gas-hydrate petroleum system," Geologica Acta, vol. 14, no. 2, pp. 79-100, 2016.

[75] Z. Wan, Y. Yao, K. Chen, S. Zhong, B. Xia, and Y. Sun, "Characterization of mud volcanoes in the northern Zhongjiannan basin, western South China Sea," Geological Journal, vol. 54, no. 1, pp. 177-189, 2019.

[76] J. Liang, J. W. Zhang, J. Lu, J. Wei, and Y. He, "Geological occurrence and accumulation mechanism of natural gas hydrates in the eastern Qiongdongnan Basin of the South China Sea: insights from site GMGS5-W9-2018," Marine Geology, vol. 418, article 106042, pp. 1-19, 2019.

[77] W. Zhang, J. Q. Liang, P. B. Su et al., "Distribution and characteristics of mud diapirs, gas chimneys, and bottom simulating reflectors associated with hydrocarbon migration and gas hydrate accumulation in theQiongdongnan Basin, northern slope of theSouth China Sea," Geological Journal, vol. 54, no. 6, pp. 3556-3573, 2019.

[78] W. Zhang, J. Liang, X. Yang, P. Su, and Z. Wan, "The formation mechanism of mud diapirs and gas chimneys and their relationship with natural gas hydrates: insights from the deep-water area of Qiongdongnan Basin, northern South China Sea," International Geology Review, vol. 62, no. 7-8, pp. 789-810, 2020.

[79] D. Wang, F. Ning, J. Lu et al., "Reservoir characteristics and critical influencing factors on gas hydrate accumulations in 
the Shenhu area, South China Sea," Marine and Petroleum Geology, vol. 133, article 105238, 2021.

[80] W. Zhang, J. Liang, J. Wei et al., "Geological and geophysical features of and controls on occurrence and accumulation of gas hydrates in the first offshore gas-hydrate production test region in the Shenhu area, Northern South China Sea," Marine and Petroleum Geology, vol. 114, no. 104191, p. 104191, 2020.

[81] W. ZHANG, J. LIANG, J.'. LU et al., “Accumulation features and mechanisms of high saturation natural gas hydrate in Shenhu area, northern South China Sea," Petroleum Exploration and Development, vol. 44, no. 5, pp. 708-719, 2017.

[82] J. Wei, J. Liang, J. Lu, W. Zhang, and Y. He, "Characteristics and dynamics of gas hydrate systems in the northwestern South China Sea - results of the fifth gas hydrate drilling expedition," Marine and Petroleum Geology, vol. 110, pp. 287-298, 2019.

[83] C. Berndt, G. Crutchley, I. Klaucke et al., "Geological controls on the gas hydrate system of Formosa Ridge, South China Sea," in OCEANS 2014 - TAIPEI, Taipei, Taiwan, 2014.

[84] J. Wei, J. Li, T. Wu et al., "Geologically controlled intermittent gas eruption and its impact on bottom water temperature and chemosynthetic communities-a case study in the "HaiMa" cold seeps, South China Sea," Geological Journal, vol. 55, no. 9, pp. 6066-6078, 2020.

[85] G. Zhang, J. Liang, J. Lu et al., "Geological features, controlling factors and potential prospects of the gas hydrate occurrence in the east part of the Pearl River Mouth Basin, South China Sea," Marine and Petroleum Geology, vol. 67, pp. 356-367, 2015.

[86] Z. Sha, J. Liang, G. Zhang et al., "A seepage gas hydrate system in northern South China Sea: seismic and well log interpretations," Marine Geology, vol. 366, pp. 69-78, 2015.

[87] S. X. Yang, M. Zhang, J. Q. Liang et al., "Preliminary results of China's third gas hydrate drilling expedition: a critical step from discovery to development in the South China Sea," Fire in the Ice, vol. 15, no. 2, pp. 1-5, 2015.

[88] S. X. Yang, J. Q. Liang, J. A. Lu, C. W. Qu, and B. Liu, "New understandings on the characteristics and controlling factors of gas hydrate reservoirs in the Shenhu area on the northern slope of the South China Sea," Earth Science Frontiers, vol. 2, no. 4, pp. 1-14, 2017.

[89] S. X. Yang, J. Q. Liang, Y. Lei et al., "GMGS4 gas hydrate drilling expedition in the South China Sea," Fire in the Ice: Methane Hydrate Newsletter, vol. 17, no. 1, pp. 7-11, 2017.

[90] S. X. Yang, Y. Lei, J. Q. Liang et al., "Concentrated gas hydrate in the Shenhu area, South China Sea: results from drilling expeditions GMGS3 \& GMGS4," in In Proceedings of 9th International Conference on Gas Hydrates, Denver, 2017Paper No. 105.

[91] S. X. Yang, H. Q. Zhang, N. Y. Wu et al., "High concentration hydrate in disseminated forms obtained in Shenhu area, North Slope of South China Sea," in Proceedings of the 6th International Conference on Gas Hydrate (ICGH 2008), Vancouver, British Columbia, Canada, 2008.

[92] E. Suess and IFMGEOMAR, Fs Sonne Fahrtbericht/Cruise Report So 177 Siger 2004, Sino-German Cooperative Project: South China Sea Continental Margin: Geological Methane Budget and Environmental Effects of Methane Emissions and Gas Hydrates; Cooperative Research between IFMGEOMAR, Kiel, Germany and Guangzhou Marine Geological Survey, China Geological Survey, Guangzhou, Guangdong Province, P.R. China, 2005, 02.06. -19.07.2004. IFM-GEOMAR Report.
[93] X. Han, E. Suess, Y. Huang, N. Wu, and Y. Fang, "Jiulong methane reef: microbial mediation of seep carbonates in the South China Sea," Marine Geology, vol. 249, no. 3-4, pp. 243-256, 2008.

[94] G. Zhong, J. Liang, Y. Guo, Z. Kuang, P. Su, and L. Lin, "Integrated core-log facies analysis and depositional model of the gas hydrate- bearing sediments in the northeastern continental slope, South China Sea," Marine and Petroleum Geology, vol. 86, pp. 1159-1172, 2017.

[95] C. Y. Huang, C. W. Chien, M. X. Zhao, H. C. Li, and Y. Iizuka, "Geological study of active cold seeps in the syn-collision accretionary prism Kaoping slope off sw Taiwan," Terrestrial, Atmospheric and Oceanic Sciences, vol. 17, no. 4, pp. 679-702, 2006.

[96] L. Cao, C. Lian, X. Zhang et al., “_In situ_detection of the fine scale heterogeneity of active cold seep environment of the Formosa Ridge, the South China Sea," Journal of Marine Systems, vol. 218, article 103530, 2021.

[97] C. S. Liu, P. Schnurle, Y. S. Wang, S. H. Chung, S. C. Chen, and T. H. Hsiuan, "Distribution and characters of gas hydrate offshore of southwestern Taiwan," Terrestrial Atmospheric and Oceanic Sciences, vol. 17, no. 4, pp. 615-644, 2006.

[98] W. T. Jiang, J. C. Chen, B. J. Huang et al., "Mineralogy and physical properties of cored se diments from the gas hydrate potential area of offshore southwestern Taiwan," Terrestrial Atmospheric and Oceanic Sciences, vol. 17, no. 4, pp. 9811007, 2006.

[99] P. Schnurle, C. S. Liu, T. H. Hsiuan, and T. K. Wang, "Characteristics of gas hydrate and free gas offshore southwestern Taiwan from a combined mcs/obs data analysis," Marine Geophysical Researches, vol. 25, no. 1-2, pp. 157180, 2004.

[100] L. Chen, W. C. Chi, S. K. Wu et al., "Two dimensional fluid flow models at two gas hydrate sites offshore southwestern Taiwan," Journal of Asian Earth Sciences, vol. 92, no. 1, pp. 245-253, 2014.

[101] J. Feng, S. Yang, H. Wang, J. Liang, Y. Fang, and M. Luo, "Methane source and turnover in the shallow sediments to the west of Haima cold seeps on the northwestern slope of the South China Sea," Geofluids, vol. 2019, Article ID 1010824, 18 pages, 2019.

[102] Z. Wan, C. Chen, J. Liang, W. Zhang, W. Huang, and P. Su, "Hydrochemical characteristics and evolution mode of cold seeps in the Qiongdongnan Basin, South China Sea," Geofluids, vol. 2020, no. 4578967, Article ID 4578967, 16 pages, 2020.

[103] D. X. Chen, X. J. Wang, D. Völker et al., “Three dimensional seismic studies of deep-water hazard-related features on the northern slope of South China Sea," Marine and Petroleum Geology, vol. 77, pp. 1125-1139, 2016.

[104] C. Cheng, T. Jiang, Z. Kuang et al., "Characteristics of gas chimneys and their implications on gas hydrate accumulation in the Shenhu area, northern south China sea," Journal of Natural Gas Science and Engineering, vol. 84, p. 103629, 2020.

[105] J. Shang, Z. Sha, J. Liang, and L. Wu, “Acoustic reflections of shallow gas on the northern slope of South China Sea and implications for gas hydrate exploration," Marine Geological Frontiers, vol. 29, no. 10, pp. 23-30, 2013.

[106] J. Shang, L. Wu, J. Liang, and Z. Sha, “The microtopographic features and gas seep model on the slope in the northeastern 
South China Sea," Marine Geology and Quaternary Geology, vol. 34, no. 1, pp. 129-136, 2014.

[107] Z. Chen, C. Y. Huang, W. Yan, M. H. Chen, L. U. Jun, and S. H. Wang, "Authigenic carbonates as evidence for seeping fluids in Xisha Trough of South China Sea," Journal of Tropical Oceanography, vol. 27, no. 6, pp. 26-33, 2007.

[108] S. Wang, W. Yan, Z. Chen, N. Zhang, and H. Chen, "Rare earth elements in cold seep carbonates from the southwestern Dongsha area, northern South China Sea," Marine and Petroleum Geology, vol. 57, pp. 482-493, 2014.

[109] D. G. Yoo, N. K. Kang, B. Y. Yi et al., "Occurrence and seismic characteristics of gas hydrate in the Ulleung Basin, East Sea," Marine and Petroleum Geology, vol. 47, pp. 236247, 2013.

[110] Z. Kuang, Y. Fang, J. Liang, J. Lu, and L. Wang, "Geomorphological-geological-geophysical signatures of high-flux fluid flows in the eastern Pearl River Mouth Basin and effects on gas hydrate accumulation," Science China Earth Sciences, vol. 61, no. 7, pp. 914-924, 2018.

[111] K. Zhang, H. B. Song, S. Q. Sun, and J. Y. Gao, “Distribution and genesis of submarine landslides in the northeastern South China Sea," Geological Journal, vol. 56, pp. 11871201, 2021.

[112] X. J. Wang, T. S. Collett, M. W. Lee, S. Yang, Y. Guo, and $\mathrm{S}$. Wu, "Geological controls on the occurrence of gas hydrate from core, downhole log, and seismic data in the Shenhu area, South China Sea," Marine Geology, vol. 357, pp. 272292, 2014.

[113] M. Su, Z. Sha, C. Zhang et al., "Types, characteristics and significances of Migrating pathways of gas-bearing fluids in the Shenhu area, northern continental slope of the South China Sea," Acta Geologica Sinica - English Edition, vol. 91, no. 1, pp. 219-231, 2017.

[114] Z. Lin, X. Sun, Y. Lu et al., "Stable isotope patterns of coexisting pyrite and gypsum indicating variable methane flow at a seep site of the Shenhu area, South China Sea," Journal of Asian Earth Sciences, vol. 123, pp. 213-223, 2016.

[115] H. Chen, Z. Chen, W. Yan, S. Wang, R. Xiang, and J. Liu, "Characteristics of authigenic minerals in sediments of core 08CF7 in Shenhu area in northern South China Sea: implications for methane seepage," Natural Gas Industry, vol. 34, no. 2, pp. 154-162, 2014.

[116] Y. Hu, D. Feng, J. Peckmann et al., "The impact of diffusive transport of methane on pore-water and sediment geochemistry constrained by authigenic enrichments of carbon, sulfur, and trace elements: a case study from the Shenhu area of the South China Sea," Chemical Geology, vol. 553, 2020.

[117] Z. du, X. Zhang, S. Xi et al., “_In situ_ Raman spectroscopy study of synthetic gas hydrate formed by cold seep flow in the South China Sea," Journal of Asian Earth Sciences, vol. 168, pp. 197-206, 2018.

[118] P. Xiong, H. Lu, X. Xie et al., "Geochemical responses and implications for gas hydrate accumulation: case study from site SHC in Shenhu Area within northern South China Sea," Marine and Petroleum Geology, vol. 111, pp. 650-661, 2020.

[119] J. Li, J. Lu, D. Kang et al., "Lithological characteristics and hydrocarbon gas sources of gas hydrate- bearing sediments in the Shenhu area, South China Sea: implications from the W01B and W02B sites," Marine Geology, vol. 408, pp. 3647, 2019.
[120] X. J. Wang, J. P. Jin, Y. Q. Guo et al., "The characteristics of gas hydrate accumulation and quantitative estimation in the North Slope of South China Sea," Earth Science, vol. 46, no. 3, pp. 1038-1057, 2021.

[121] L. Yang, B. Liu, M. Xu, S. Liu, and Y. Gu, "Characteristics of active cold seepages in Qiongdongnan Sea Area of the northern South China Sea," Chinese Journal of Geophysics, vol. 61, no. 7, pp. 2905-2914, 2018.

[122] K. Zhang, H. Song, H. Wang et al., "A preliminary study on the active cold seeps flow field in the Qiongdongnan Sea Area, the northern South China Sea," Chinese Science Bulletin, vol. 65, no. 12, pp. 1130-1140, 2020.

[123] J. Wang, S. Wu, X. Kong et al., "Subsurface fluid flow at an active cold seep area in the Qiongdongnan Basin, northern South China Sea," Journal of Asian Earth Sciences, vol. 168, pp. 17-26, 2018.

[124] H. H. Hsu, C. S. Liu, S. Morita et al., "Seismic imaging of the Formosa ridge cold seep site offshore of southwestern Taiwan," Marine Geophysical Research, vol. 39, no. 4, pp. 523$535,2018$.

[125] H. F. Lai, Y. X. Fang, Z. G. Kuang et al., "Geochemistry, origin and accumulation of natural gas hydrates in the qiongdongnan basin, South China Sea: implications from site GMGS5W08," Marine and Petroleum Geology, vol. 123, article 104774, 2020

[126] W. C. Han, L. Chen, C. S. Liu, C. Berndt, and W. C. Chi, "Seismic analysis of the gas hydrate system at Pointer Ridge offshore SW Taiwan," Marine and Petroleum Geology, vol. 105, pp. 158-167, 2019.

[127] P. Schnürle, C. S. Liu, A. T. Lin, and S. Lin, "Structural controls on the formation of BSR over a diapiric anticline from a dense MCS survey offshore southwestern Taiwan," Marine and Petroleum Geology, vol. 28, no. 10, pp. 1932-1942, 2011.

[128] N. Wu, S. Yang, H. Zhang, J. Liang, and J. Lu, "Gas hydrate system of Shenhu area, northern South China Sea: wire-line logging, geochemical results and preliminary resources estimates," Proceedings of the Annual Offshore Technology Conference, vol. 1, no. 1, 2010.

[129] N. Wu, H. Zhang, S. Yang et al., "Gas hydrate system of Shenhu area, northern South China Sea: geochemical results," Journal of Geological Research, vol. 2011, 10 pages, 2011.

[130] N. Chen, T. Yang, W. Hong et al., "Production, consumption, and migration of methane in accretionary prism of southwestern Taiwan," Geochemistry, Geophysics, Geosystems, vol. 18, no. 8, pp. 2970-2989, 2017.

[131] J. DAI, Y. NI, S. HUANG et al., "Genetic types of gas hydrates in China," Petroleum Exploration and Development, vol. 44, no. 6, pp. 887-898, 2017.

[132] W. Zhang, J. Liang, J. Wei, P. Su, L. Lin, and W. Huang, "Origin of natural gases and associated gas hydrates in the Shenhu area, northern South China Sea: results from the China gas hydrate drilling expeditions," Journal of Asian Earth Sciences, vol. 183, article 103953, 2019.

[133] Z. Sha, J. Liang, P. Su, G. Zhang, J. Lu, and J. Wang, "Natural gas hydrate accumulation elements and drilling results analysis in the eastern part of the Pearl River Mouth Basin," Earth Science Frontiers, vol. 22, no. 6, pp. 125-135, 2015.

[134] W. Zhang, J. Liang, J. Lu et al., "Characteristics and controlling mechanism of typical leakage gas hydrate reservoir forming system in the Qiongdongnan Basin, northern South 
China Sea," Natural Gas Industry, vol. 40, no. 8, pp. 90-99, 2020.

[135] Z. H. U. Youhai, H. U. A. N. G. Xia, F. U. Shaoying, and S. U. Pibo, "Gas sources of natural gas hydrates in the Shenhu drilling area, South China Sea: geochemical evidence and geological analysis," Acta Geologica Sinica (English Edition), vol. 87, no. 3, pp. 767-776, 2013.

[136] X. Huang, Y. H. Zhu, Z. Q. Lu, and P. K. Wang, "Study on genetic types of hydrocarbon gases from the gas hydrate drilling area, the northern South China Sea," Geoscience, vol. 24, no. 3, pp. 576-580, 2010.

[137] J. Ye, X. Qin, H. Qiu et al., "Data report: molecular and isotopic compositions of the extracted gas from China's first offshore natural gas hydrate production test in South China Sea," Energies, vol. 11, no. 10, p. 2793, 2018.

[138] J. Jin, X. Wang, Y. Guo et al., "Geological controls on the occurrence of recently formed highly concentrated gas hydrate accumulations in the Shenhu area, South China Sea," Marine and Petroleum Geology, vol. 116, 2020.

[139] J. X. He, S. H. Chen, H. L. Liu, and S. L. Liu, "Natural gas genetic types and source rocks in the northern slope of Baiyun Sag to Panyu Low Uplift in Pearl River Mouth Basin," Acta Petrolei Sinica, vol. 30, no. 1, pp. 16-21, 2009.

[140] J. X. Dai, The coal-formed large gas fields and their gas sources in China, Science Press, Beijing, 2014.

[141] Z. Sha, Z. Xu, S. Fu et al., "Gas sources and its implications for hydrate accumulation in the eastern Pearl River Mouth Basin," Marine Geology and Quaternary Geology, vol. 39, no. 4, pp. 116-125, 2019.

[142] J. Gong, X. Sun, L. Xu, and H. Lu, "Contribution of thermogenic organic matter to the formation of biogenic gas hydrate: evidence from geochemical and microbial characteristics of hydrate- containing sediments in the Taixinan Basin, South China Sea," Marine and Petroleum Geology, vol. 80, pp. 432-449, 2017.

[143] Y. Li, Y. Fang, Q. Zhou et al., "Geochemical insights into contribution of petroleum hydrocarbons to the formation of hydrates in the Taixinan Basin, the South China Sea," Geoscience Frontiers, no. article 100974, 2020.

[144] N. C. Chen, T. F. Yang, W. L. Hong et al., "Discharge of deeply rooted fluids from submarine mud volcanism in the Taiwan accretionary prism," Scientific Reports, vol. 10, no. $1,2020$.

[145] B. Beauchamp, J. C. Harrison, W. W. Nassichuk, H. R. Krouse, and L. S. Eliuk, "Cretaceous cold-seep communities and methane-derived carbonates in the Canadian arctic," Science, vol. 244, no. 4900, pp. 53-56, 1989.

[146] B. Wang, Z. Du, Z. Luan et al., "Seabed features associated with cold seep activity at the Formosa Ridge, South China Sea: integrated application of high-resolution acoustic data and photomosaic images," Deep Sea Research Part I: Oceanographic Research Papers, vol. 177, article 103622, 2021.

[147] W. Zhang, J. He, Z. Lu, P. Su, X. Li, and Z. Liu, "Preliminary study of the relationship between the suspected mud diapir and natural gas hydrate in the Qiongdongnan Basin," Northern South China Sea. Natural Gas Geosciences, vol. 26, no. 11, pp. 2185-2197, 2015.

[148] D. Wei, L. Jinqiang, Z. Wei, K. Zenggui, Z. Tong, and H. Yulin, "Typical characteristics of fracture-filling hydratecharged reservoirs caused by heterogeneous fluid flow in the
Qiongdongnan Basin, northern South China Sea," Marine and Petroleum Geology, vol. 124, article 104810, 2020.

[149] J. Wei, T. Wu, W. Zhang et al., "Deeply buried authigenic carbonates in the Qiongdongnan Basin, South China Sea: implications for ancient cold seep activities," Minerals, vol. 10, no. 1135, pp. 1-19, 2020.

[150] M. Hovland, "Gas-induced erosion features in the north sea," Earth Surface Processes and Landforms, vol. 9, no. 3, pp. 209228, 2010.

[151] E. Suess, G. Bohrmann, D. Rickert, W. F. Kuhs, M. E. Torres, and A. M. Tréhu, "Properties and near-surface methane hydrates at hydrate ridge, Cascadia margin," in Proceedings International Gas Hydrate Research Conference, Yokohama, 2002.

[152] X. Q. Han, K. H. Yang, and Y. Y. Huang, "Origin and nature of cold seep in northeastern Dongsha area, South China Sea: evidence from chimney-like seep carbonates," Chinese Science Bulletin, vol. 58, no. 30, pp. 3689-3697, 2013.

[153] A. G. Judd, "The global importance and context of methane escape from the seabed," Geo-Marine Letters, vol. 23, no. 34, pp. 147-154, 2003.

[154] P. Su, J. Liang, J. Peng, W. Zhang, and J. Xu, "Petroleum systems modeling on gas hydrate of the first experimental exploitation region in the Shenhu area, northern South China Sea," Journal of Asian Earth Sciences, vol. 168, pp. 57-76, 2018.

[155] Y. Z. Zhang, X. D. Xu, J. Gan, J. T. Zhu, X. X. Guo, and X. H. $\mathrm{He}$, "Study on the geological characteristics, accumulation model and exploration direction of the giant deepwater gas field in the Qiongdongnan Basin," Acta Geologica Sinica, vol. 91, no. 7, pp. 1620-1633, 2017.

[156] Y. Zhang, J. Gan, X. Xu, G. Liang, and X. Li, "The source and natural gas lateral migration accumulation model of Y8-1 gas bearing structure, east deep water in the Qiongdongnan Basin," Earth Science, vol. 44, no. 8, pp. 2609-2618, 2019.

[157] O. Y. Zatsepina and B. A. Buffett, "Phase equilibrium of gas hydrate: implications for the formation of hydrate in the deep sea floor," Geophysical Research Letters, vol. 24, no. 13, pp. 1567-1570, 1997.

[158] B. A. Buffett and O. Y. Zatsepina, "Formation of gas hydrate from dissolved gas in natural porous media," Marine Geology, vol. 164, no. 1-2, pp. 69-77, 2000.

[159] M. W. Lee and T. S. Collett, "Pore- and fracture-filling gas hydrate reservoirs in the Gulf of Mexico gas hydrate joint industry project leg II Green Canyon $955 \mathrm{H}$ well," Marine and Petroleum Geology, vol. 34, no. 1, pp. 62-71, 2012.

[160] A. E. Cook, D. Goldberg, and R. L. Kleinberg, "Fracture-controlled gas hydrate systems in the northern Gulf of Mexico," Marine and Petroleum Geology, vol. 25, no. 9, pp. 932-941, 2008.

[161] R. Ghosh, K. Sain, and M. Ojha, "Effective medium modeling of gas hydrate-filled fractures using the sonic log in the Krishna-Godavari Basin, offshore eastern India," Journal of Geophysical Research Solid Earth, vol. 115, no. B6, 2010.

[162] M. W. Lee and T. S. Collett, "Characteristics and interpretation of fracture-filled gas hydrate - an example from the Ulleung Basin, East Sea of Korea," Marine and Petroleum Geology, vol. 47, pp. 168-181, 2013.

[163] S.-C. Chen, S.-K. Hsu, Y. Wang et al., "Distribution and characters of the mud diapirs and mud volcanoes off southwest Taiwan," Journal of Asian Earth Sciences, vol. 92, pp. 201214, 2014 
[164] I. W. Aiello, R. E. Garrison, J. C. Moore, M. Kastner, and D. S. Stakes, "Anatomy and origin of carbonate structures in a miocene cold-seep field," Geology, vol. 29, no. 12, pp. 360364, 2001.

[165] V. Liebetrau, N. Augustin, S. Kutterolf et al., "Cold-seepdriven carbonate deposits at the central American forearc: contrasting evolution and timing in escarpment and mound settings," International Journal of Earth Sciences, vol. 103, no. 7, pp. 1845-1872, 2014.

[166] J. W. Pohlman, J. E. Bauer, E. A. Canuel et al., "Methane sources in gas hydrate-bearing cold seeps: evidence from radiocarbon and stable isotopes," Marine Chemistry, vol. 115, no. 1-2, pp. 102-109, 2009.

[167] B. Ritt, C. Pierre, O. Gauthier, F. Wenzhofer, A. Boetius, and J. Sarrazin, "Diversity and distribution of cold-seep fauna associated with different geological and environmental settings at mud volcanoes and pockmarks of the Nile deep-sea fan," Marine Biology, vol. 158, no. 6, pp. 1187-1210, 2011. 